\title{
Metabolite Profiling of Triterpene Glycosides of the Far Eastern Sea Cucumber Eupentacta fraudatrix and Their Distribution in Various Body Components Using LC-ESI QTOF-MS
}

\author{
Roman S. Popov ${ }^{1}$, Natalia V. Ivanchina ${ }^{1}$, Alexandra S. Silchenko ${ }^{1}$, Sergey A. Avilov ${ }^{1}$, \\ Vladimir I. Kalinin ${ }^{1}$, Igor Yu. Dolmatov ${ }^{2,3}$, Valentin A. Stonik ${ }^{1,3}$ and Pavel S. Dmitrenok ${ }^{1, *}$ \\ 1 G.B. Elyakov Pacific Institute of Bioorganic Chemistry, Far Eastern Branch of Russian Academy of Sciences, \\ 159 Prospect 100-letiya Vladivostoka, Vladivostok 690022, Russia; prs_90@mail.ru (R.S.P.); \\ ivanchina@piboc.dvo.ru (N.V.I.); sialexandra@mail.ru (A.S.S.); avilov-1957@mail.ru (S.A.A.); \\ kalininv@piboc.dvo.ru (V.I.K.); stonik@piboc.dvo.ru (V.A.S.) \\ 2 A.V. Zhirmunsky Institute of Marine Biology, National Scientific Center of Marine Biology, \\ Far Eastern Branch of the Russian Academy of Sciences, 17 Palchevskogo St., Vladivostok 690041, Russia; \\ idolmatov@mail.ru \\ 3 School of Natural Science, Far Eastern Federal University, 8 Sukhanova St., Vladivostok 690090, Russia \\ * Correspondence: paveldmt@piboc.dvo.ru; Tel.: +7-423-231-1132
}

Received: 18 August 2017; Accepted: 30 September 2017; Published: 2 October 2017

\begin{abstract}
The Far Eastern sea cucumber Eupentacta fraudatrix is an inhabitant of shallow waters of the south part of the Sea of Japan. This animal is an interesting and rich source of triterpene glycosides with unique chemical structures and various biological activities. The objective of this study was to investigate composition and distribution in various body components of triterpene glycosides of the sea cucumber E. fraudatrix. We applied LC-ESI MS (liquid chromatography-electrospray mass spectrometry) of whole body extract and extracts of various body components for metabolic profiling and structure elucidation of triterpene glycosides from the E. fraudatrix. Totally, 54 compounds, including 26 sulfated, 18 non-sulfated and 10 disulfated glycosides were detected and described. Triterpene glycosides from the body walls, gonads, aquapharyngeal bulbs, guts and respiratory trees were extracted separately and the distributions of the detected compounds in various body components were analyzed. Series of new glycosides with unusual structural features were described in E. fraudatrix, which allow clarifying the biosynthesis of these compounds. Comparison of the triterpene glycosides contents from the five different body components revealed that the profiles of triterpene glycosides were qualitatively similar, and only some quantitative variabilities for minor compounds were observed.
\end{abstract}

Keywords: sea cucumber; Eupentacta fraudatrix; triterpene glycoside; liquid chromatography-tandem mass spectrometry; metabolite profiling

\section{Introduction}

Sea cucumbers (Class Holothuroidea, Phylum Echinodermata) are widespread slow-moving marine animals. Metabolome of these animals is characterized by the high content of triterpene glycosides of a great structural diversity. Triterpene glycosides of sea cucumbers have unique chemical structures, significantly differing from those of terrestrial plants. These compounds possess a variety of biological and pharmacological effects including cytotoxic [1,2], antifungal [3,4], bactericidal, hemolytic, antiviral and antiparasitic properties [5]. Some glycosides are capable to induce apoptosis, inhibit the 
growth of tumor cells [6] and have immunomodulatory properties [7]. In addition, certain species of sea cucumbers are a valuable maricultural resource [8].

Majority of triterpene glycosides from sea cucumbers possess a lanostane-type aglycone with an 18(20)-lactone called as holostane derivatives. Individual triterpene aglycones differ from each other in the number and arrangement of oxygen substituents, double bonds and in the structure of the side chains demonstrating a significant natural diversity. Some triterpene glycosides have aglycones with 18(16)-lactone or without a lactone cycle. Usually, triterpene glycosides have a polycyclic nucleus with 7(8)- or 9(11)-double bond and oxygen-containing substituents, which may be bonded to C-12, C-17 or C-16. The side chains of aglycones may have one or more double bonds, hydroxyl or acetate groups and other substituents. Some glycosides have aglycones with shortened side chains.

The oligosaccharide chain of triterpene glycosides is attached to C-3 of the aglycone and may include up to six sugar units. Oligosaccharide chains with up to four monosaccharide units usually have a linear structure, while the penta- and hexaosides contain a branching at the first or second monosaccharide unit. Xylose (Xyl), glucose (Glc), quinovose (Qui), 3-O-methylglucose (MeGlc), and, rarely, 3-O-methylxylose (MeXyl) are the most common sugar residues in triterpene glycosides. The first unit in oligosaccharide chain is always xylose, quinovose (rarely glucose or xylose) is usually the second monosaccharide unit and glucose (or xylose) is the third [1,4]. The methylated monosaccharides always occupy the terminal position. Many glycosides have up to three sulfate groups at certain positions of the oligosaccharide chain.

It is supposed that triterpene glycosides have multiple defensive roles such as defense against predators, parasites and microorganisms. Indeed, a high percentage of these compounds in the Cuvierian tubules, that can be ejected toward a predator as well as their strong ichthyotoxic and membranolytic effects indicate their effective action against predators $[9,10]$. In addition, it is likely that glycosides play an important role in regulating the reproduction of sea cucumbers [11].

Triterpene glycosides display taxonomic specificity for different systematic groups of sea cucumbers. The level of this specificity may be different in various sea cucumbers taxa. The glycoside structures are specific for one genus or a group of genera for the sea cucumbers of the order Aspidochirotida. However, these compounds are usually species-specific for the representatives of the order Dendrochirotida [12].

Triterpene glycosides are usually present in extracts of sea cucumbers as complex mixtures. Minor compounds of these extracts remain largely unstudied, although knowledge about their chemical structures is also important for understanding of biosynthesis and biological roles of these compounds. Recent investigations have demonstrated the power of MS approaches for profiling and for studying of the body distribution of sea cucumber triterpene glycosides [13,14]. All sea cucumbers contain triterpene glycosides in their body walls and viscera; however, recent studies have demonstrated difference in content of these metabolites in the Cuvierian tubules and in the body wall. All the glycosides, detected in the body walls of Holothuria forskali were found to be also present in the Cuvierian tubules but the latter also contain specific congeners. Furthermore, profiles of triterpene glycosides in both analyzed body parts varied under stress condition $[9,10,15]$.

The sea cucumber Eupentacta fraudatrix (Djakonov et Baranova) (=Cucumaria fraudatrix Djakonov et Baranova $=$ Cucumaria obunca Lampert) (Family Sclerodactylidae, Order Dendrochirotida) is a common species in the shallow waters of the south part of the Sea of Japan and is a rich source of triterpene glycosides. E. fraudatrix is a well-studied species that is often used as a model organism in biological studies of various processes such as development [16,17], regeneration [18-20] and immunity [21-23]. The previous investigations of the sea cucumber E. fraudatrix have led to isolation of 37 triterpene glycosides comprising 15 non-sulfated tetraosides (cucumariosides $A_{1}-A_{15}$ [24-26]), two non-sulfated triosides (cucumariosides $B_{1}$ and $B_{2}$ [27]), two non-sulfated pentaosides (cucumariosides $C_{1}$ and $C_{2}$ [28]), 4 sulfated tetraosides (cucumariosides $G_{1}-G_{4}$ [29-32]), eight sulfated pentaosides (cucumariosides $\mathrm{H}, \mathrm{H}_{2}-\mathrm{H}_{8}$ [33-35]), two disulfated tetraosides (cucumariosides $\mathrm{F}_{1}$ and $\mathrm{F}_{2}$ [36]), and four disulfated pentaosides (cucumariosides $\mathrm{I}_{1}-\mathrm{I}_{4}[37,38]$ ). The majority of the glycosides from 
E. fraudatrix are characterized by the presence of 3-O-MeXyl residue as terminal unit in carbohydrate chain, which is considered a chemotaxonomic marker of the genus Eupentacta. Herein, we describe the application of LC-ESI MS for metabolic profiling, evaluation of the structural variability, structure elucidation and further refinement of known biosynthetic patterns of triterpene glycosides from the sea cucumber E. fraudatrix. In addition, triterpene glycosides from the body walls, gonads, aquapharyngeal bulbs, guts and respiratory trees were extracted separately and distribution of the detected compounds in various body components were analyzed.

\section{Results and Discussion}

\subsection{Profiling and Structural Identification of the Triterpene Glycosides from E. fraudatrix}

Profiling of triterpene glycosides from the whole body extract of the sea cucumber E. fraudatrix using LC-MS approach allowed numerous new as well as previously isolated triterpene glycosides to be characterized. The HPLC profile revealed at least 54 compounds, including 26 sulfated, 18 non-sulfated and 10 disulfated glycosides (Figures 1 and 2; Table 1; Figure S1; the numbers of the compounds correspond to the peak numbers on (-)LC-MS chromatogram).

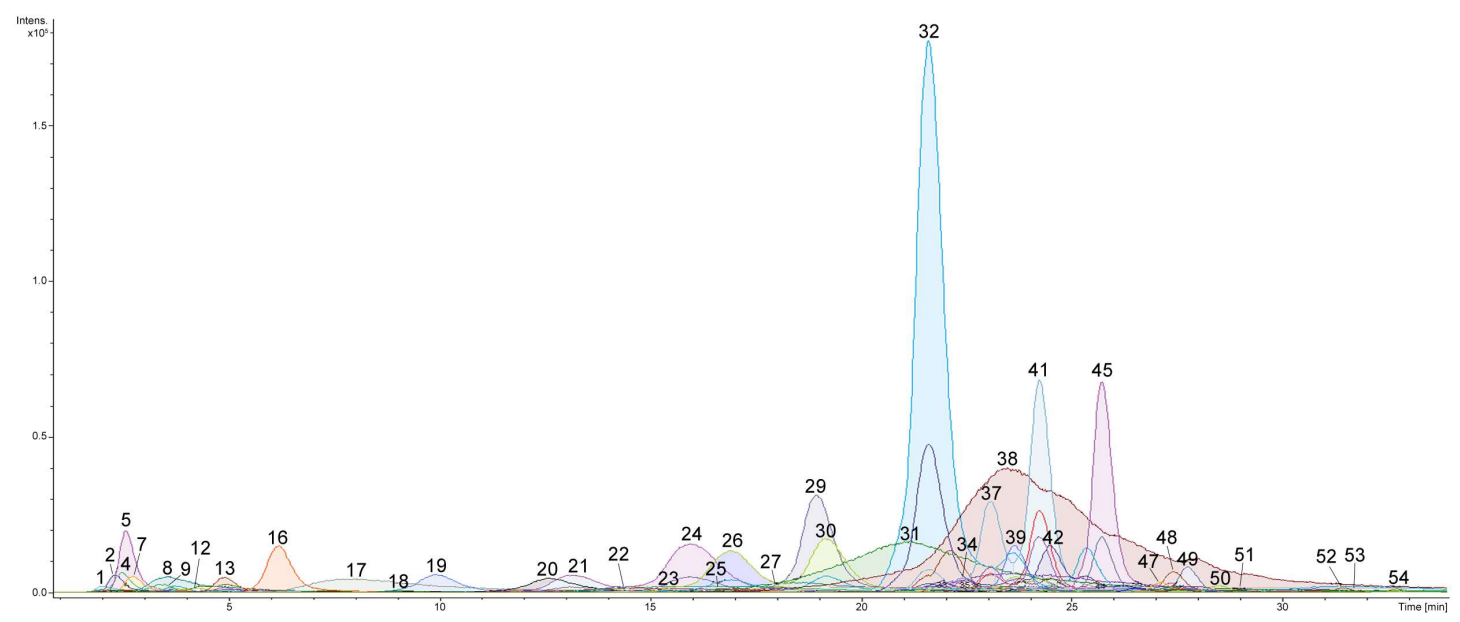

Figure 1. LC-ESI MS (liquid chromatography-electrospray mass spectrometry) total compounds chromatogram of detected triterpene glycosides in negative ion mode (sulfated, disulfated and non-sulfated glycosides were detected as $[\mathrm{M}-\mathrm{Na}]^{-},[\mathrm{M}-2 \mathrm{Na}]^{2-}$ and $[\mathrm{M}-\mathrm{H}]^{-}$ions) in ethanol extract of sea cucumber Eupentacta fraudatrix.

In positive ion mode, the majority of triterpene glycosides were detected within $m / z$ range from 1000 to 1400 a.m.u. as $[\mathrm{M}+\mathrm{Na}]^{+}$ions. However, stable peaks of $[\mathrm{M}+\mathrm{Na}]^{+}$ions for disulfated glycosides were not observed in these conditions. In negative ion mode, sulfated and disulfated glycosides were detected as $[\mathrm{M}-\mathrm{Na}]^{-}$and $[\mathrm{M}-2 \mathrm{Na}]^{2-}$ peaks, respectively, whereas non-sulfated compounds were detected as $[\mathrm{M}-\mathrm{H}]^{-}$peaks.

The assignments of these compounds in all samples analyzed were based on the data of high resolution LC-MS and LC-MS/MS performed in both negative and positive ion modes. Elemental composition, determined on the base of high resolution data (mass accuracy tolerance $<2 \mathrm{ppm}$ ), fragmentation patterns of MS and MS/MS spectra, as well as chromatographic behavior of the corresponding compounds, allowed their structures to be proposed. It is known that triterpene glycosides are characterized by large structural variability. Generally, mass spectrometry does not permit to determine configuration of the unknown compounds. Besides, different epimeric monosaccharides as well as types of bonds between sugars cannot be strictly distinguished only by MS. However, the combination of the obtained data and biosynthetic considerations allows tentative structural assignments for the detected compounds. 


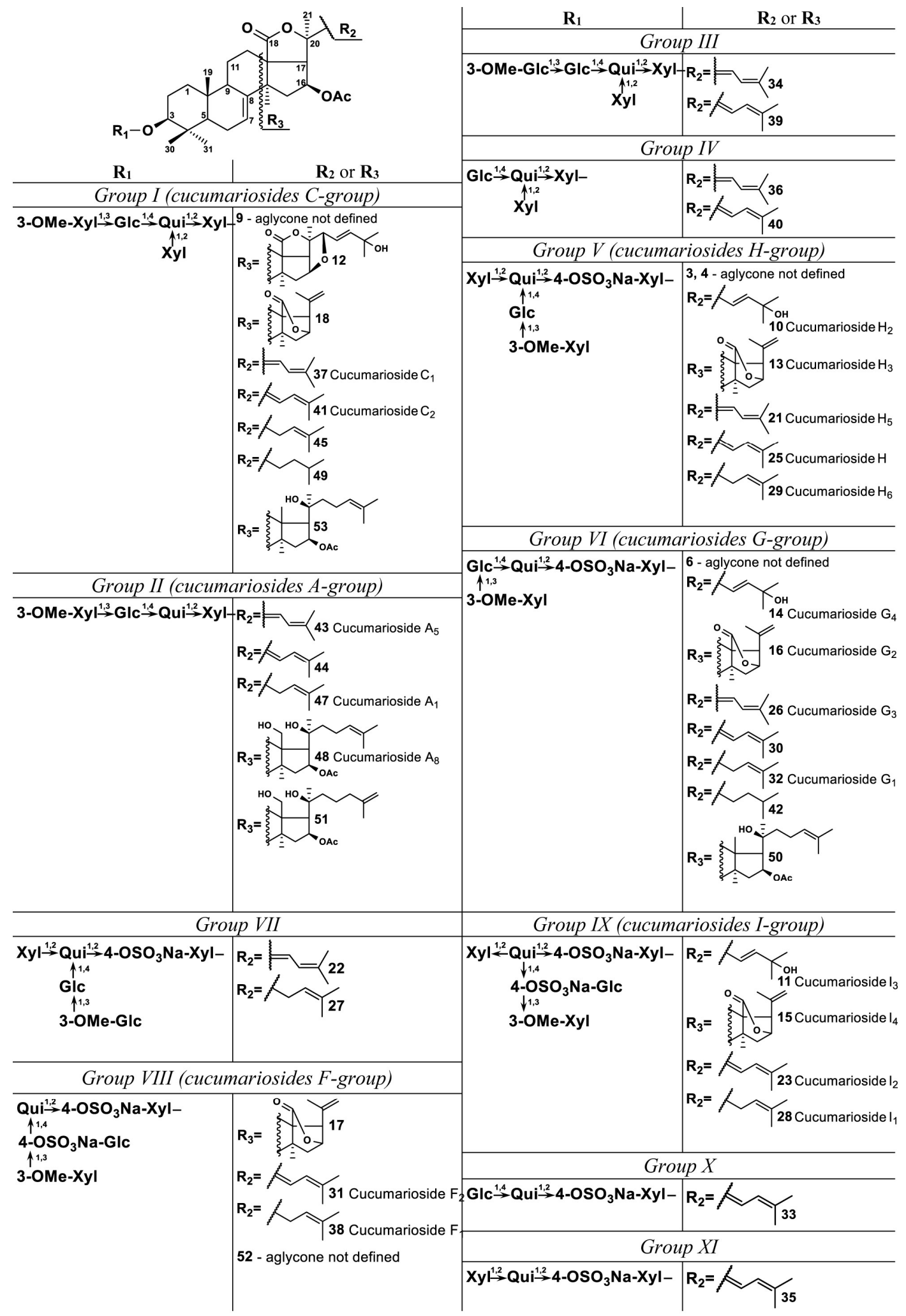

Figure 2. Structures of triterpene glycosides identified $(10,11,13,14,15,16,21,23,25,26,28,29,31,32$, $37,38,41,43,47$, and 48) and proposed $(12,17,18,22,27,30,33,34,35,36,39,40,42,44,45,49,50,51$, and 53) from the sea cucumber E. fraudatrix by LC-MS/MS method. 
Table 1. Triterpene glycosides of the ethanol extract of the sea cucumber E. fraudatrix detected by LC-ESI MS and their concentrations in different organs.

\begin{tabular}{|c|c|c|c|c|c|c|c|c|c|c|c|c|}
\hline \multirow{2}{*}{ No. ${ }^{a}$} & \multirow{2}{*}{$\begin{array}{c}R_{t} \\
(\min )\end{array}$} & \multirow{2}{*}{$\begin{array}{c}\text { Elemental } \\
\text { Composition }\end{array}$} & \multirow{2}{*}{$\begin{array}{c}\text { Measured } \\
\mathrm{m} / \mathrm{z}\end{array}$} & \multirow{2}{*}{$\begin{array}{l}\text { Molecular } \\
\text { Ion Type }\end{array}$} & \multirow{2}{*}{$\begin{array}{l}\text { Calculated } \\
\quad m / z\end{array}$} & \multirow{2}{*}{$\Delta(\mathrm{ppm})$} & \multicolumn{5}{|c|}{ Content of Detected Compounds in Different Organs $(\mu \mathrm{g} / \mathrm{g})^{\mathrm{c}}$} & \multirow{2}{*}{ Identification (ChemSpider ID) } \\
\hline & & & & & & & BW & GN & G & $\mathrm{AB}$ & RT & \\
\hline 1 & 2.0 & $\mathrm{C}_{53} \mathrm{H}_{83} \mathrm{O}_{28} \mathrm{SNa}$ & 1199.4788 & {$[\mathrm{M}-\mathrm{Na}]^{-}$} & 1199.4797 & 0.8 & 1.28 & 2.07 & 0.74 & 4.41 & 5.06 & \\
\hline 2 & 2.3 & $\mathrm{C}_{58} \mathrm{H}_{91} \mathrm{O}_{31} \mathrm{SNa}$ & 1315.5265 & {$[\mathrm{M}-\mathrm{Na}]^{-}$} & 1315.5271 & 0.4 & 2.06 & 3.89 & 2.02 & 10.76 & 12.19 & \\
\hline 3 & 2.4 & $\mathrm{C}_{60} \mathrm{H}_{93} \mathrm{O}_{31} \mathrm{SNa}$ & 1341.5430 & {$[\mathrm{M}-\mathrm{Na}]^{-}$} & 1341.5427 & -0.2 & 0.58 & 3.02 & 0.51 & 2.15 & 1.98 & \\
\hline 4 & 2.5 & $\mathrm{C}_{57} \mathrm{H}_{85} \mathrm{O}_{30} \mathrm{SNa}$ & 1281.4854 & {$[\mathrm{M}-\mathrm{Na}]^{-}$} & 1281.4852 & -0.2 & 3.12 & 7.12 & 2.21 & 11.88 & 16.15 & \\
\hline 5 & 2.6 & $\mathrm{C}_{53} \mathrm{H}_{83} \mathrm{O}_{27} \mathrm{SNa}$ & 1183.4848 & {$[\mathrm{M}-\mathrm{Na}]^{-}$} & 1183.4848 & 0.0 & 8.51 & 12.85 & 6.27 & 33.07 & 39.82 & \\
\hline 6 & 2.7 & $\mathrm{C}_{55} \mathrm{H}_{85} \mathrm{O}_{27} \mathrm{SNa}$ & 1209.4998 & {$[\mathrm{M}-\mathrm{Na}]^{-}$} & 1209.5004 & 0.5 & 0.89 & 4.65 & 0.61 & 2.50 & 2.50 & \\
\hline 7 & 2.8 & $\mathrm{C}_{52} \mathrm{H}_{77} \mathrm{O}_{26} \mathrm{SNa}$ & 1149.4426 & {$[\mathrm{M}-\mathrm{Na}]^{-}$} & 1149.4429 & 0.3 & 2.30 & 7.72 & 2.00 & 10.60 & 12.71 & \\
\hline 8 & 3.5 & $\mathrm{C}_{53} \mathrm{H}_{82} \mathrm{O}_{30} \mathrm{~S}_{2} \mathrm{Na}_{2}$ & 631.2170 & {$[\mathrm{M}-2 \mathrm{Na}]^{2-}$} & 631.2172 & 0.3 & 7.23 & 13.08 & 5.68 & 26.16 & 27.96 & \\
\hline 9 & 3.8 & $\mathrm{C}_{57} \mathrm{H}_{86} \mathrm{O}_{27}$ & 1201.5275 & {$[\mathrm{M}-\mathrm{H}]^{-}$} & 1201.5284 & 0.7 & 19.90 & 63.76 & 21.23 & 82.84 & 132.97 & \\
\hline 10 & 4.0 & $\mathrm{C}_{60} \mathrm{H}_{93} \mathrm{O}_{30} \mathrm{SNa}$ & 1325.5472 & {$[\mathrm{M}-\mathrm{Na}]^{-}$} & 1325.5478 & 0.4 & 2.05 & 3.45 & 2.13 & 3.96 & 3.21 & Cucumarioside $\mathrm{H}_{2}$ * (ID29215132) \\
\hline 11 & 4.3 & $\mathrm{C}_{60} \mathrm{H}_{92} \mathrm{O}_{33} \mathrm{~S}_{2} \mathrm{Na}_{2}$ & 702.2493 & {$[\mathrm{M}-2 \mathrm{Na}]^{2-}$} & 702.2487 & -0.9 & 5.40 & 5.53 & 5.24 & 4.21 & 3.49 & Cucumarioside $\mathrm{I}_{3}{ }^{*}$ (ID30771157) \\
\hline 12 & 4.3 & $\mathrm{C}_{58} \mathrm{H}_{90} \mathrm{O}_{26}$ & 1201.5634 & {$[\mathrm{M}-\mathrm{H}]^{-}$} & 1201.5648 & 1.1 & 5.98 & 66.99 & 3.88 & 12.14 & 17.24 & \\
\hline 13 & 5.0 & $\mathrm{C}_{53} \mathrm{H}_{81} \mathrm{O}_{27} \mathrm{SNa}$ & 1181.4692 & {$[\mathrm{M}-\mathrm{Na}]^{-}$} & 1181.4691 & 0.0 & 67.31 & 65.70 & 56.11 & 38.44 & 22.47 & Cucumarioside $\mathrm{H}_{3}{ }^{*}$ (ID29215133) \\
\hline 14 & 5.0 & $\mathrm{C}_{55} \mathrm{H}_{85} \mathrm{O}_{26} \mathrm{SNa}$ & 1193.5051 & {$[\mathrm{M}-\mathrm{Na}]^{-}$} & 1193.5055 & 0.4 & 45.93 & 45.05 & 51.93 & 44.31 & 42.30 & Cucumarioside $\mathrm{G}_{4}{ }^{* *}$ (ID29216498) \\
\hline 15 & 5.0 & $\mathrm{C}_{53} \mathrm{H}_{80} \mathrm{O}_{30} \mathrm{~S}_{2} \mathrm{Na}_{2}$ & 630.2098 & {$[\mathrm{M}-2 \mathrm{Na}]^{2-}$} & 630.2093 & -0.7 & 31.18 & 68.95 & 44.00 & 19.20 & 11.98 & Cucumarioside $\mathrm{I}_{4} *$ (ID30771158) \\
\hline 16 & 6.2 & $\mathrm{C}_{48} \mathrm{H}_{73} \mathrm{O}_{23} \mathrm{SNa}$ & 1049.4268 & {$[\mathrm{M}-\mathrm{Na}]^{-}$} & 1049.4269 & 0.1 & 182.20 & 258.47 & 199.67 & 104.16 & 78.53 & Cucumarioside $\mathrm{G}_{2}{ }^{* *}$ (ID16737749) \\
\hline 17 & 7.7 & $\mathrm{C}_{48} \mathrm{H}_{72} \mathrm{O}_{26} \mathrm{~S}_{2} \mathrm{Na}_{2}$ & 564.1882 & {$[\mathrm{M}-2 \mathrm{Na}]^{2-}$} & 564.1882 & 0.0 & 164.93 & 533.31 & 233.14 & 86.44 & 85.75 & \\
\hline 18 & 9.1 & $\mathrm{C}_{53} \mathrm{H}_{82} \mathrm{O}_{24}$ & 1101.5126 & {$[\mathrm{M}-\mathrm{H}]^{-}$} & 1101.5123 & -0.2 & 95.81 & 79.93 & 94.56 & 92.03 & 77.07 & \\
\hline 19 & 9.9 & $\mathrm{C}_{62} \mathrm{H}_{95} \mathrm{O}_{31} \mathrm{SNa}$ & 1367.5580 & {$[\mathrm{M}-\mathrm{Na}]^{-}$} & 1367.5584 & 0.3 & 131.88 & 158.75 & 151.50 & 88.37 & 59.04 & \\
\hline 20 & 12.4 & $\mathrm{C}_{57} \mathrm{H}_{87} \mathrm{O}_{27} \mathrm{SNa}$ & 1235.5156 & {$[\mathrm{M}-\mathrm{Na}]^{-}$} & 1235.5161 & 0.4 & 87.55 & 123.77 & 115.97 & 76.27 & 67.76 & \\
\hline 21 & 13.0 & $\mathrm{C}_{60} \mathrm{H}_{91} \mathrm{O}_{29} \mathrm{SNa}$ & 1307.5369 & {$[\mathrm{M}-\mathrm{Na}]^{-}$} & 1307.5372 & 0.2 & 102.46 & 101.10 & 101.29 & 75.06 & 56.43 & Cucumarioside $\mathrm{H}_{5}$ * (ID29212282) \\
\hline 22 & 14.4 & $\mathrm{C}_{61} \mathrm{H}_{93} \mathrm{O}_{30} \mathrm{SNa}$ & 1337.5472 & {$[\mathrm{M}-\mathrm{Na}]^{-}$} & 1337.5478 & 0.4 & 39.15 & 33.91 & 27.47 & 30.81 & 26.60 & \\
\hline 23 & 14.5 & $\mathrm{C}_{60} \mathrm{H}_{90} \mathrm{O}_{32} \mathrm{~S}_{2} \mathrm{Na}_{2}$ & 693.2437 & {$[\mathrm{M}-2 \mathrm{Na}]^{2-}$} & 693.2434 & -0.5 & 132.94 & 144.25 & 135.53 & 117.55 & 79.00 & Cucumarioside $\mathrm{I}_{2}$ * \\
\hline 24 & 15.6 & $\mathrm{C}_{57} \mathrm{H}_{86} \mathrm{O}_{30} \mathrm{~S}_{2} \mathrm{Na}_{2}$ & 657.2330 & {$[\mathrm{M}-2 \mathrm{Na}]^{2-}$} & 657.2328 & -0.3 & 164.12 & 260.64 & 225.03 & 129.11 & 119.00 & \\
\hline 25 & 15.7 & $\mathrm{C}_{60} \mathrm{H}_{91} \mathrm{O}_{29} \mathrm{SNa}$ & 1307.5370 & {$[\mathrm{M}-\mathrm{Na}]^{-}$} & 1307.5372 & 0.2 & 355.92 & 300.10 & 325.16 & 257.61 & 205.87 & Cucumarioside $\mathrm{H}^{* *}$ \\
\hline 26 & 16.8 & $\mathrm{C}_{55} \mathrm{H}_{83} \mathrm{O}_{25} \mathrm{SNa}$ & 1175.4946 & {$[\mathrm{M}-\mathrm{Na}]^{-}$} & 1175.4950 & 0.3 & 157.60 & 196.62 & 189.16 & 161.61 & 191.52 & Cucumarioside $\mathrm{G}_{3}{ }^{* *}$ (ID29213085) \\
\hline 27 & 17.8 & $\mathrm{C}_{61} \mathrm{H}_{95} \mathrm{O}_{30} \mathrm{SNa}$ & 1339.5629 & {$[\mathrm{M}-\mathrm{Na}]^{-}$} & 1339.5634 & 0.4 & 24.08 & 25.54 & 25.95 & 22.53 & 24.23 & \\
\hline 28 & 18.1 & $\mathrm{C}_{60} \mathrm{H}_{92} \mathrm{O}_{32} \mathrm{~S}_{2} \mathrm{Na}_{2}$ & 694.2510 & {$[\mathrm{M}-2 \mathrm{Na}]^{2-}$} & 694.2512 & 0.3 & 188.33 & 207.58 & 222.25 & 202.43 & 149.95 & Cucumarioside $\mathrm{I}_{1} *$ (ID30771156) \\
\hline 29 & 19.0 & $\mathrm{C}_{60} \mathrm{H}_{93} \mathrm{O}_{29} \mathrm{SNa}$ & 1309.5524 & {$[\mathrm{M}-\mathrm{Na}]^{-}$} & 1309.5529 & 0.4 & 349.25 & 387.00 & 349.37 & 310.11 & 243.40 & Cucumarioside $\mathrm{H}_{6}{ }^{*}$ (ID29212283) \\
\hline 30 & 19.1 & $\mathrm{C}_{55} \mathrm{H}_{83} \mathrm{O}_{25} \mathrm{SNa}$ & 1175.4946 & {$[\mathrm{M}-\mathrm{Na}]^{-}$} & 1175.4950 & 0.3 & 196.05 & 245.41 & 225.43 & 159.63 & 183.33 & \\
\hline 31 & 20.8 & $\mathrm{C}_{55} \mathrm{H}_{82} \mathrm{O}_{28} \mathrm{~S}_{2} \mathrm{Na}_{2}$ & 627.2223 & {$[\mathrm{M}-2 \mathrm{Na}]^{2-}$} & 627.2223 & -0.1 & 650.73 & 1465.87 & 1013.44 & 492.83 & 518.87 & Cucumarioside $\mathrm{F}_{2} *$ (ID34981778) \\
\hline 32 & 21.5 & $\mathrm{C}_{55} \mathrm{H}_{85} \mathrm{O}_{25} \mathrm{SNa}$ & 1177.5101 & {$[\mathrm{M}-\mathrm{Na}]^{-}$} & 1177.5106 & 0.4 & 1399.21 & 990.35 & 1149.58 & 1114.02 & 1446.29 & Cucumarioside $\mathrm{G}_{1}^{* *}$ (ID29212825) \\
\hline 33 & 21.8 & $\mathrm{C}_{49} \mathrm{H}_{73} \mathrm{O}_{21} \mathrm{SNa}$ & 1029.4364 & {$[\mathrm{M}-\mathrm{Na}]^{-}$} & 1029.4371 & 0.6 & 3.49 & 4.46 & 4.22 & 3.38 & 2.41 & \\
\hline 34 & 22.4 & $\mathrm{C}_{61} \mathrm{H}_{94} \mathrm{O}_{27}$ & 1257.5905 & {$[\mathrm{M}-\mathrm{H}]^{-}$} & 1257.5910 & 0.4 & 353.39 & 277.23 & 270.44 & 373.37 & 400.82 & \\
\hline 35 & 22.4 & $\mathrm{C}_{48} \mathrm{H}_{71} \mathrm{O}_{20} \mathrm{SNa}$ & 999.4257 & {$[\mathrm{M}-\mathrm{Na}]^{-}$} & 999.4265 & 0.8 & 4.00 & 4.03 & 4.08 & 3.80 & 3.78 & \\
\hline 36 & 22.5 & $\mathrm{C}_{54} \mathrm{H}_{82} \mathrm{O}_{22}$ & 1081.5224 & {$[\mathrm{M}-\mathrm{H}]^{-}$} & 1081.5225 & 0.1 & 20.68 & 29.78 & 40.22 & 19.97 & 12.52 & \\
\hline 37 & 23.1 & $\mathrm{C}_{60} \mathrm{H}_{92} \mathrm{O}_{26}$ & 1227.5799 & {$[\mathrm{M}-\mathrm{H}]^{-}$} & 1227.5804 & 0.4 & 2304.76 & 1883.92 & 1982.79 & 2465.98 & 2218.90 & Cucumarioside $C_{1} * *$ \\
\hline 38 & 23.2 & $\mathrm{C}_{55} \mathrm{H}_{84} \mathrm{O}_{28} \mathrm{~S}_{2} \mathrm{Na}_{2}$ & 628.2301 & {$[\mathrm{M}-2 \mathrm{Na}]^{2-}$} & 628.2301 & 0.0 & 1397.27 & 1896.52 & 1889.40 & 1520.29 & 1581.81 & Cucumarioside $\mathrm{F}_{1}$ * (ID34981780) \\
\hline 39 & 23.6 & $\mathrm{C}_{61} \mathrm{H}_{94} \mathrm{O}_{27}$ & 1257.5907 & {$[\mathrm{M}-\mathrm{H}]^{-}$} & 1257.5910 & 0.2 & 1232.75 & 844.94 & 836.78 & 1248.59 & 1121.92 & \\
\hline 40 & 23.8 & $\mathrm{C}_{54} \mathrm{H}_{82} \mathrm{O}_{22}$ & 1081.5221 & {$[\mathrm{M}-\mathrm{H}]^{-}$} & 1081.5225 & 0.4 & 78.61 & 99.33 & 141.63 & 60.09 & 38.25 & \\
\hline
\end{tabular}


Table 1. Cont

\begin{tabular}{|c|c|c|c|c|c|c|c|c|c|c|c|c|}
\hline \multirow{2}{*}{ No. ${ }^{a}$} & \multirow{2}{*}{$\begin{array}{c}\mathrm{R}_{\mathrm{t}} \\
(\min )\end{array}$} & \multirow{2}{*}{$\begin{array}{c}\text { Elemental } \\
\text { Composition }\end{array}$} & \multirow{2}{*}{$\begin{array}{c}\text { Measured } \\
\mathrm{m} / \mathrm{z}\end{array}$} & \multirow{2}{*}{$\begin{array}{l}\text { Molecular } \\
\text { Ion Type }\end{array}$} & \multirow{2}{*}{$\begin{array}{c}\text { Calculated } \\
m / z\end{array}$} & \multirow{2}{*}{$\Delta(\mathrm{ppm})$} & \multicolumn{5}{|c|}{ Content of Detected Compounds in Different Organs $(\mu \mathrm{g} / \mathrm{g})^{\mathrm{c}}$} & \multirow{2}{*}{ Identification (ChemSpider ID) } \\
\hline & & & & & & & BW & GN & G & $\mathrm{AB}$ & RT & \\
\hline 41 & 24.2 & $\mathrm{C}_{60} \mathrm{H}_{92} \mathrm{O}_{26}$ & 1227.5796 & {$[\mathrm{M}-\mathrm{H}]^{-}$} & 1227.5804 & 0.7 & 5042.17 & 3983.86 & 4978.07 & 4965.12 & 4323.97 & Cucumarioside $C_{2} * *$ \\
\hline 42 & 24.5 & $\mathrm{C}_{55} \mathrm{H}_{87} \mathrm{O}_{25} \mathrm{SNa}$ & 1179.5253 & {$[\mathrm{M}-\mathrm{Na}]^{-}$} & 1179.5263 & 0.8 & 107.49 & 63.87 & 80.66 & 86.34 & 113.97 & \\
\hline 43 & 24.6 & $\mathrm{C}_{55} \mathrm{H}_{84} \mathrm{O}_{22}$ & 1095.5380 & {$[\mathrm{M}-\mathrm{H}]^{-}$} & 1095.5381 & 0.1 & 30.86 & 30.40 & 35.66 & 40.90 & 55.20 & Cucumarioside $A_{5} * *$ (ID29214535) \\
\hline 45 & 25.7 & $\mathrm{C}_{60} \mathrm{H}_{94} \mathrm{O}_{26}$ & 1229.5956 & {$[\mathrm{M}-\mathrm{H}]^{-}$} & 1229.5961 & 0.4 & 3169.77 & 3565.18 & 3696.87 & 4227.02 & 3920.64 & \\
\hline 46 & 26.6 & $\mathrm{C}_{47} \mathrm{H}_{75} \mathrm{O}_{18} \mathrm{SNa}$ & 959.4674 & {$[\mathrm{M}-\mathrm{Na}]^{-}$} & 959.4680 & 0.6 & 4.31 & 5.66 & 5.78 & 4.76 & 6.27 & \\
\hline 47 & 27.1 & $\mathrm{C}_{55} \mathrm{H}_{86} \mathrm{O}_{22}$ & 1097.5534 & {$[\mathrm{M}-\mathrm{H}]^{-}$} & 1097.5538 & 0.4 & 128.12 & 114.38 & 137.12 & 144.01 & 155.36 & Cucumarioside $A_{1} *$ (ID29214532) \\
\hline 48 & 27.5 & $\mathrm{C}_{55} \mathrm{H}_{90} \mathrm{O}_{22}$ & 1101.5851 & {$[\mathrm{M}-\mathrm{H}]^{-}$} & 1101.5851 & 0.0 & 38.22 & 39.78 & 38.21 & 45.55 & 54.26 & Cucumarioside $A_{8}$ * (ID29215118) \\
\hline 49 & 27.7 & $\mathrm{C}_{60} \mathrm{H}_{96} \mathrm{O}_{26}$ & 1231.6110 & {$[\mathrm{M}-\mathrm{H}]^{-}$} & 1231.6117 & 0.6 & 328.18 & 276.91 & 355.16 & 406.50 & 399.65 & \\
\hline 51 & 28.9 & $\mathrm{C}_{55} \mathrm{H}_{90} \mathrm{O}_{22}$ & 1101.5843 & {$[\mathrm{M}-\mathrm{H}]^{-}$} & 1101.5851 & 0.7 & 19.39 & 17.88 & 17.46 & 18.56 & 21.60 & \\
\hline 52 & 31.3 & $\mathrm{C}_{55} \mathrm{H}_{84} \mathrm{O}_{27} \mathrm{~S}_{2} \mathrm{Na}_{2}$ & 620.2328 & {$[\mathrm{M}-2 \mathrm{Na}]^{2-}$} & 620.2326 & -0.3 & 52.92 & 53.12 & 56.30 & 58.02 & 62.22 & \\
\hline 53 & 31.4 & $\mathrm{C}_{60} \mathrm{H}_{98} \mathrm{O}_{25}$ & 1217.6314 & {$[\mathrm{M}-\mathrm{H}]^{-}$} & 1217.6324 & 0.9 & 34.13 & 32.21 & 31.91 & 35.58 & 44.22 & \\
\hline 54 & 32.6 & $\mathrm{C}_{56} \mathrm{H}_{92} \mathrm{O}_{23}$ & 1131.5951 & {$[\mathrm{M}-\mathrm{H}]^{-}$} & 1131.5957 & 0.5 & 19.77 & 18.64 & 21.13 & 23.62 & 19.24 & \\
\hline
\end{tabular}


It is known that the majority of triterpene glycosides have a xylose at C-3 of the aglycone as the first monosaccharide unit, quinovose as the second monosaccharide unit, and glucose (or xylose) as the third monosaccharide unit in the main chain [1,4]. Methylated monosaccharides are always terminal units. Considering that the oligosaccharide chains of earlier isolated triterpene glycosides from this sea cucumber are closely related to each other and have general architecture 3-O-methyl- $\beta$-D-xylopyranosyl-( $1 \rightarrow 3)-\beta$-D-glucopyranosyl-( $1 \rightarrow 4)-\beta$-D-quinovopyranosyl-( $1 \rightarrow 2)-\beta$-Dxylopyranosyl in the linear part of carbohydrate chains and may have $\beta$-D-xylopyranosyl- $(1 \rightarrow 2)$ in the branching at the second monosaccharide, some suggestions concerning structures of oligosaccharide chains of unknown glycosides may be proposed. In addition, most of the previously isolated glycosides of E. fraudatrix have a $16 \beta$-acetoxyholosta-7-ene aglycone. These common structural features give a possibility to propose structures for a series of newly identified glycosides.

The structures of detected glycosides were characterized by tandem MS. The (-)MS/MS provided many product ion series arising from the cleavages of both glycosidic bonds and bond of aglycone side chain. (+)MS/MS provided an intense B- and C-type product ion series (nomenclature according to Domon and Costello [39]) arising from the cleavages of glycosidic bonds with charge located on saccharide fragment (Table S1). These product ion series are characteristic and provided information about the sequence of monosaccharide units in carbohydrate chains. For example, the positive product ion spectrum of $[\mathrm{M}+\mathrm{Na}]^{+}$precursor at $m / z 1251.5776$ (compound 41) exhibits extensive fragmentation namely peaks at $m / z$ 169.05 [MeXyl $+\mathrm{Na}]^{+}, 331.10[\mathrm{MeXyl}+\mathrm{Glc}+\mathrm{Na}]^{+}$, $349.11\left[\mathrm{MeXyl}+\mathrm{Glc}+\mathrm{H}_{2} \mathrm{O}+\mathrm{Na}^{+}, 389.14\left[\mathrm{MeXyl}+\mathrm{Glc}+\mathrm{C}_{3} \mathrm{H}_{6} \mathrm{O}+\mathrm{Na}^{+}\right.\right.$, $417.14\left[\mathrm{MeXyl}+\mathrm{Glc}+\mathrm{C}_{4} \mathrm{H}_{6} \mathrm{O}_{2}+\mathrm{Na}^{+}, 477.16\left[\mathrm{MeXyl}+\mathrm{Glc}+\mathrm{Qui}+\mathrm{Na}^{+}\right.\right.$, $537.18\left[\mathrm{MeXyl}+\mathrm{Glc}+\mathrm{Qui}+\mathrm{C}_{2} \mathrm{H}_{4} \mathrm{O}_{2}+\mathrm{Na}\right]^{+}, 609.20[\mathrm{MeXyl}+\mathrm{Glc}+\mathrm{Qui}+\mathrm{Xyl}+\mathrm{Na}]^{+}$, 627.21 [MeXyl + Glc + Qui + Xyl $\left.+\mathrm{H}_{2} \mathrm{O}+\mathrm{Na}\right]^{+}, 669.22\left[\mathrm{MeXyl}+\mathrm{Glc}+\mathrm{Qui}+\mathrm{Xyl}+\mathrm{C}_{2} \mathrm{H}_{4} \mathrm{O}_{2}+\mathrm{Na}\right]^{+}$, $741.24[\mathrm{MeXyl}+\mathrm{Glc}+\mathrm{Qui}+2 \mathrm{Xyl}+\mathrm{Na}]^{+}$, and $759.25\left[\mathrm{MeXyl}+\mathrm{Glc}+\mathrm{Qui}+2 \mathrm{Xyl}+\mathrm{H}_{2} \mathrm{O}+\mathrm{Na}\right]^{+}$ (Figure 3). This fragmentation pattern corresponded to a branched non-sulfated oligosaccharide chain consisting of five monosaccharide units and compound $\mathbf{4 1}$ was identified as cucumarioside $C_{2}$.

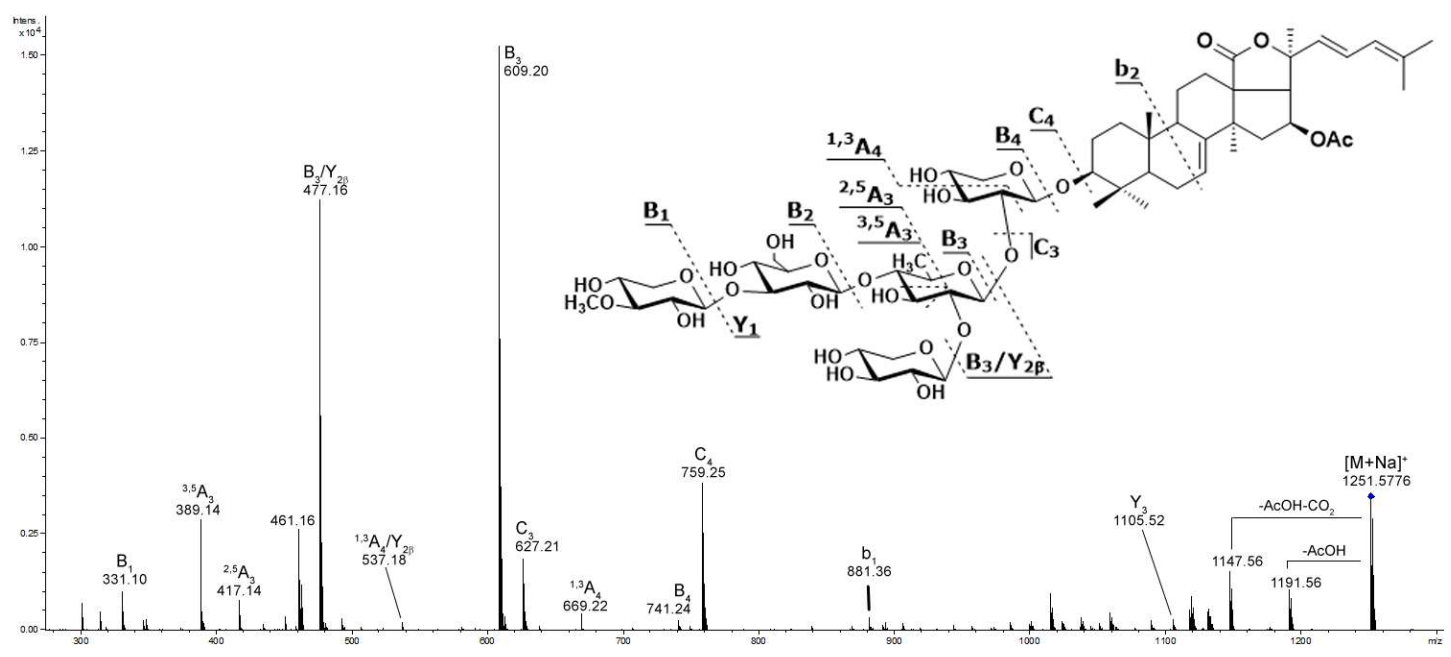

Figure 3. ESI MS/MS spectrum of $[\mathrm{M}+\mathrm{Na}]^{+}$precursor ion at $m / z 1251$ identified as cucumarioside $\mathrm{C}_{2}$ (41).

In some cases, several typical mass losses between the precursor and the fragment ions were detected in product ion spectra. These typical mass losses are related to the aglycone and provide information about the structure of nucleus and side chain. In MS/MS spectra of the majority of the glycosides, a mass loss of 60 Da between the precursor and the intense fragment ion was detected (for example, Figure S2). This corresponds to the loss of $\mathrm{C}_{2} \mathrm{H}_{4} \mathrm{O}_{2}$ molecule (acetic acid) and is a characteristic of the glycosides containing an acetoxy group [40]. Next intense fragment ion with a mass loss $104 \mathrm{Da}$ from the precursor corresponds to the loss of a $\left[\mathrm{C}_{2} \mathrm{H}_{4} \mathrm{O}_{2}+\mathrm{CO}_{2}\right]$ fragment and is 
characteristic for the glycosides containing an acetoxy group and a 18(20)-lactone cycle. Analysis of the MS/MS spectra of a number of triterpene glycosides isolated earlier allowed to identify characteristic fragment peaks related with the cleavages of side chains. For example, $(+)$ MS/MS spectra of the cucumarioside $\mathrm{A}_{1}$ with 24-ene side chain have a mass loss of $228.1359 \mathrm{Da}$, corresponding to the loss of a C $_{12} \mathrm{H}_{20} \mathrm{O}_{4}$ fragment (Figure S2). The (+)MS/MS spectra of the glycosides with 22,24-diene system in the side chain display a characteristic mass loss of $\mathrm{C}_{11} \mathrm{H}_{17} \mathrm{O}_{4}$ fragments (213.1121 Da). Otherwise, spectra of cucumarioside $\mathrm{A}_{15}$ with saturated side chain display a characteristic mass losses of fragments $\mathrm{C}_{12} \mathrm{H}_{22} \mathrm{O}_{4}(230.1525 \mathrm{Da})$ and $\mathrm{C}_{10} \mathrm{H}_{10} \mathrm{O}_{4}(204.1370 \mathrm{Da})$. These fragmentation patterns enable to propose structural features of aglycones for newly identified glycosides.

In accordance with the structures of oligosaccharide chains, all detected glycosides of $E$. fraudatrix can be divided into eleven groups (I-XI). Compounds of group I $(9,12,18,37,41,45,49$, and 53) had branched non-sulfated oligosaccharide chain consisting of five monosaccharide units-methylated xylose, glucose, quinovose and xylose in the main chain and xylose as branching unit at the second monosaccharide. Such type of oligosaccharide chain corresponds to known cucumariosides of the C-group. Obtained data allowed to identify the glycosides $37\left(\mathrm{~m} / z 1227.5799[\mathrm{M}-\mathrm{H}]^{-}\right.$, calcd 1227.5804) as cucumarioside $\mathrm{C}_{1}$ and $41\left(\mathrm{~m} / z 1227.5796[\mathrm{M}-\mathrm{H}]^{-}\right.$, calcd 1227.5804) as cucumarioside $C_{2}$ [28]. These compounds have similar holostane type aglycones having $16 \beta$-OAc and 7(8)-double bond in the nucleus and two double bonds in side chains which differ in the configuration of C-22 (22Z,24-diene system for cucumarioside $C_{1}$ and 22E,24-diene system for cucumarioside $C_{2}$ ). As a result, these compounds have similar MS/MS spectra, but their retention times differ (Rt of 37 is $23.1 \mathrm{~min}$, and Rt of $\mathbf{4 1}-24.2 \mathrm{~min}$ ). It was found that the glycosides with 22Z,24-diene system in the side chain have shorter retention time then analogous compounds with 22E,24-diene system. This made it possible to identify such pairs of similar compounds. In addition, (+)MS/MS spectra of 37 and 41 have characteristic mass losses of $204 \mathrm{Da}$ and $213 \mathrm{Da}$, which confirm their structure. Compounds $45\left(m / z 1229.5956[\mathrm{M}-\mathrm{H}]^{-}\right.$, calcd 1229.5961) and $49\left(\mathrm{~m} / \mathrm{z} 1231.6110[\mathrm{M}-\mathrm{H}]^{-}\right.$, calcd 1231.6117) differed in 2 and $4 \mathrm{Da}$, respectively, versus compounds 37 and 41. Their MS/MS spectra were similar to the spectra of compounds 37 and $\mathbf{4 1}$, but in (+)MS/MS spectrum of 45 a characteristic fragment peak $\left[\mathrm{M}+\mathrm{Na}-\mathrm{C}_{12} \mathrm{H}_{20} \mathrm{O}_{4}\right]^{+}$was detected at $m / z$ 1025.4557, and in (+)MS/MS spectrum of 49 the fragment peaks $\left[\mathrm{M}+\mathrm{Na}-\mathrm{C}_{12} \mathrm{H}_{22} \mathrm{O}_{4}\right]^{+}$and $\left[\mathrm{M}+\mathrm{Na}-\mathrm{C}_{10} \mathrm{H}_{20} \mathrm{O}_{4}\right]^{+}$were detected at $m / z 1025.4550$ and 1051.4709, respectively. This indicates the presence of one double bond in $\mathbf{4 5}$ and no double bonds in the side chain of 49 . All these data revealed that 45 has a $16 \beta$-acetoxyholosta-7,24-diene aglycone and 49 has $16 \beta$-acetoxyholosta-7-ene aglycone. Structures of these two compounds are similar to known cucumariosides $\mathrm{A}_{1}$ and $\mathrm{A}_{15}$, respectively, with additional xylose as branching monosaccharide unit. Aglycone of glycoside $18\left(\mathrm{~m} / z 1101.5126[\mathrm{M}-\mathrm{H}]^{-}\right.$, calcd 1101.5123) has no fragmentation in tandem MS; HR MS and chromatographic behavior of this compound corresponds to that having a 23,24,25,26,27-pentanorlanostane aglycone with an 18(16)-lactone. Compound 12 $(\mathrm{m} / z 1201.5634 \text { [M }-\mathrm{H}]^{-}$, calcd 1201.5648) may has 16S,22R-epoxy-holosta-7,23E-diene-25-ol aglycone. Such aglycone was previously found in cucumarioside $\mathrm{H}_{8}$, a sulfated derivative of $\mathbf{1 2}$ [33]. MS/MS data of $53\left(\mathrm{~m} / \mathrm{z} 1217.6314[\mathrm{M}-\mathrm{H}]^{-}\right.$, calcd 1217.6324) showed that this compound has an aglycone with one oxygen less than some other aglycones of this group. The presence of a characteristic fragment peak $\left[\mathrm{M}+\mathrm{Na}-\mathrm{C}_{9} \mathrm{H}_{18} \mathrm{O}\right]^{+}$at $m / z 1099.4918$ may indicate that the aglycone of 53 has no $\gamma$-lactone moiety and probably has a structure of 16-acetoxy-20-hydroxy-lanosta-7,24-diene. The structure of the aglycone of glycoside 9 was not defined.

The compounds of group II $(43,44,47,48$, and 51) have a linear non-sulfated oligosaccharide chain with four monosaccharides-methylated xylose, glucose, quinovose and xylose. Such type of oligosaccharide chain corresponds to known cucumariosides of the A-group. Glycoside 47 $\left(m / z\right.$ 1097.5534 $[\mathrm{M}-\mathrm{H}]^{-}$, calcd 1097.5538) was identified as cucumarioside $\mathrm{A}_{1}$ based on comparison of its retention time, MS spectra and elemental composition with those of standard compound [24]. Glycoside $48\left(m / z 1101.5851[\mathrm{M}-\mathrm{H}]^{-}\right.$, calcd 1101.5851) was identified as cucumarioside $\mathrm{A}_{8}$ by analogous way as for 47 [26]. The MS data obtained for compound $51\left(\mathrm{~m} / z 1101.5843[\mathrm{M}-\mathrm{H}]^{-}\right.$, 
calcd 1101.5851) were identical of those of cucumarioside $A_{8}$ indicating similarity of structures of 51 and 48. Glycoside 51 may differ in configuration or position of the double bond in the side chain. We suggest that this glycoside contains a 20-hydroxy-25(26)-ene fragment in the aglycone. Glycoside $43\left(\mathrm{~m} / z 1095.5380[\mathrm{M}-\mathrm{H}]^{-}\right.$, calcd 1095.5381) was identified as cucumarioside $\mathrm{A}_{5}$ based on MS spectra and elemental composition [24]. This metabolite has an aglycone with 22Z,24-diene system in the side chain. Compound $44\left(\mathrm{~m} / \mathrm{z} 1095.5379[\mathrm{M}-\mathrm{H}]^{-}\right.$, calcd 1095.5381) is similar to 43, but its retention time is higher. This may indicate that $\mathbf{4 4}$ has an aglycone with 22E,24-diene system in the side chain.

Fragmentation of oligosaccharide chain of glycosides of the group III (34 and 39) was similar to fragmentation of oligosaccharide chain of glycosides of the group I, but all fragment peaks in MS/MS spectra were shifted by $30 \mathrm{Da}$ (Table S1). This may be due to the replacement of the terminal methylated xylose with a methylated glucose residue. Thus, group III includes compounds having non-sulfated main oligosaccharide chain with methylated glucose, glucose, quinovose and xylose monosaccharide units and xylose as branching unit. Data of glycosides $34\left(\mathrm{~m} / z 1257.5905[\mathrm{M}-\mathrm{H}]^{-}\right.$, calcd 1257.5910) and $39\left(\mathrm{~m} / \mathrm{z} 1257.5907[\mathrm{M}-\mathrm{H}]^{-}\right.$, calcd 1257.5910) were similar to those of cucumariosides $C_{1}$ (37) and $C_{2}$ (41), respectively. This may indicate that glycosides 34 and 39 have the same $16 \beta$-acetoxyholosta-7-ene aglycone with 22Z,24-diene system for 34 and 22E,24-diene system for 39. Actually, these compounds were isolated and their preliminary structures were confirmed by $1 \mathrm{D}$ NMR (Figures S6-S8).

Glycosides of group IV (40 and 36) have a non-sulfated oligosaccharide chain consisted of glucose, quinovose, and two xylose units. The presence of two Y-type fragment peaks at $m / z 973.4761$ $[\mathrm{M}+\mathrm{Na}-\mathrm{Xyl}]^{+}$and $943.4650[\mathrm{M}+\mathrm{Na}-\mathrm{Glc}]^{+}$in MS/MS of 40 indicates the oligosaccharide chain with two terminal non-methylated monosaccharides. Thus, the structure of the oligosaccharide chain of IV group glycosides was similar to those of I or III groups, without terminal methylated monosaccharide. Fragmentation pattern and HR MS data of compounds $36\left(\mathrm{~m} / z 1081.5224[\mathrm{M}-\mathrm{H}]^{-}\right.$, calcd 1081.5225) and $40\left(\mathrm{~m} / z\right.$ 1081.5221 $\left[\mathrm{M}-\mathrm{H}^{-}\right]^{-}$, calcd 1081.5225) corresponded to holostane type aglycones with $16 \beta$-OAc and 7(8)-double bond in the nucleus and side chain with two double bonds. Comparison of retention times of these glycosides indicates that 36 have 22Z,24-diene system and 40 have 22E,24-diene system in the side chains.

The group $V(3,4,10,13,21,25$, and 29) include glycosides with branched pentasaccharide chain having one sulfate group at the first xylose unit and 3-O-methyl-xylose as a terminal monosaccharide unit and belong to the group of cucumariosides $\mathrm{H}$. Structure of carbohydrate moieties were confirmed by tandem MS. Fragmentation of oligosaccharide chain of the glycosides of group $\mathrm{V}$ under collision induced dissociation (CID) conditions gave the intense characteristic product ion series of $\mathrm{A}$-, $\mathrm{B}$-and C-type ions (Table S1). Fragment ions $\mathrm{C}_{4}, \mathrm{~B}_{4}$ and $\mathrm{A}_{4}$ were mainly observed in desulfated form. In addition, CID spectra of sulfated glycosides provided characteristic product ion ${ }^{1,5} \mathrm{~A}_{4}$, arising from the cleavage of the ring of sulfated xylose unit. Glycosides $10\left(\mathrm{~m} / z 1325.5472[\mathrm{M}-\mathrm{Na}]^{-}\right.$, calcd 1325.5478), $13\left(\mathrm{~m} / \mathrm{z} 1181.4692[\mathrm{M}-\mathrm{Na}]^{-}\right.$, calcd 1181.4691), $21\left(\mathrm{~m} / z\right.$ 1307.5369 $[\mathrm{M}-\mathrm{Na}]^{-}$, calcd 1307.5372), $25\left(\mathrm{~m} / \mathrm{z} 1307.5370[\mathrm{M}-\mathrm{Na}]^{-}\right.$, calcd 1307.5372), and $29\left(\mathrm{~m} / z\right.$ 1309.5524 [M - Na] ${ }^{-}$, calcd 1309.5529) were identified as cucumariosides $\mathrm{H}_{2}, \mathrm{H}_{3}, \mathrm{H}_{5}, \mathrm{H}$, and $\mathrm{H}_{6}$, respectively, based on the comparison of their retention times, MS spectra and elemental compositions with those of standard compounds [33-35]. Structures of glycosides 3 and 4 were not defined.

Glycosides of group VI $(6,14,16,26,30,32,42$, and 50$)$ belong to the group of cucumariosides $G$, having a linear tetrasaccharide chain with one sulfate group at the first xylose unit and 3-O-methyl-xylose as a terminal monosaccharide unit. MS/MS data obtained in both negative and positive ion modes and HR mass values allowed to identify glycosides $14\left(\mathrm{~m} / \mathrm{z} 1193.5051[\mathrm{M}-\mathrm{Na}]^{-}\right.$, calcd 1193.5051) as cucumarioside $\mathrm{G}_{4}$ [30], $16\left(\mathrm{~m} / z 1049.4268[\mathrm{M}-\mathrm{Na}]^{-}\right.$, calcd 1049.4269) as cucumarioside $\mathrm{G}_{2}$ [32], $26\left(\mathrm{~m} / \mathrm{z} 1175.4946\left[\mathrm{M}-\mathrm{Na}^{-}{ }^{-}\right.\right.$, calcd 1175.4950) as cucumarioside $\mathrm{G}_{3}$ [31], and 32 $\left(m / z 1177.5101[\mathrm{M}-\mathrm{Na}]^{-}\right.$, calcd 1177.5106) as cucumarioside $\mathrm{G}_{1}$ [29]. Aglycone of $30(\mathrm{~m} / z 1175.4946$ $[\mathrm{M}-\mathrm{Na}]^{-}$, calcd 1175.4950) was identified as $16 \beta$-acetoxyholosta-7,22E,24-triene-3 $\beta$-ol. Compound 42 $\left(m / z 1179.5253\left[\mathrm{M}-\mathrm{Na}^{-}\right.\right.$, calcd 1179.5263) probably has holostane type aglycone similar to aglycone 
of 49 with $16 \beta-O A c$ and 7(8)-double bond in the nucleus and without double bonds in the side chain. Aglycone of $50\left(\mathrm{~m} / z 1165.5467[\mathrm{M}-\mathrm{Na}]^{-}\right.$, calcd 1165.5470) is similar to the aglycone of 53 and has the structure 16-acetoxy-20-hydroxy-lanosta-7,24-diene. Structure of the aglycone of glycoside 6 was not defined.

Compounds of group VII (22 and 27) have branched oligosaccharide chain consisting of five monosaccharide units-3-O-methyl-glucose as a terminal monosaccharide, glucose, quinovose and sulfated xylose in main chain and xylose as branching unit at second monosaccharide. In MS/MS spectra of glycoside $22\left(\mathrm{~m} / z 1337.5472[\mathrm{M}-\mathrm{Na}]^{-}\right.$, calcd 1337.5478) fragment peaks characteristic for a holostane aglycone with $16 \beta$-OAc and two double bonds in the side chain were detected. Obtained data indicated that $27\left(\mathrm{~m} / \mathrm{z} 1339.5629[\mathrm{M}-\mathrm{Na}]^{-}\right.$, calcd 1339.5634) probably has $16 \beta$-acetoxyholosta-7,24-diene aglycone.

The group VIII (17, 31, 38, and 52) includes compounds with linear tetrasaccharide chain containing terminal 3-O-methyl-xylose, sulfated glucose, quinovose and sulfated xylose. These glycosides belong to the group of cucumariosides F. It should be noted that in the positive ion mode it was not possible to obtain stable ions $[\mathrm{M}+\mathrm{Na}]^{+}$for disulfated glycosides, so negative ion MS/MS spectra of $[\mathrm{M}-2 \mathrm{Na}]^{2-}$ ions were used for analysis. Fragmentation of oligosaccharide chain of $[\mathrm{M}-2 \mathrm{Na}]^{2-}$ ion in MS/MS spectra of disulfated glycosides under CID conditions gave the characteristic product ion series of A-, B- and Y-types ions, which were mainly observed in desulfated form (Table S1). All data allowed identifying glycosides $31\left(\mathrm{~m} / \mathrm{z} 627.2223[\mathrm{M}-2 \mathrm{Na}]^{2-}\right.$, calcd 627.2223) as cucumarioside $\mathrm{F}_{2}$ and $38(\mathrm{~m} / z \text { 628.2301 [M }-2 \mathrm{Na}]^{2-}$, calcd 628.2301) as cucumarioside $\mathrm{F}_{1}$ [36]. Glycoside $17\left(m / z 564.1882[\mathrm{M}-2 \mathrm{Na}]^{2-}\right.$, calcd 564.1882) has 23,24,25,26,27-pentanorlanostane aglycone with an 18(16)-lactone. Structure of the aglycone of glycoside 52 was not defined.

Oligosaccharide chain of glycosides group IX (11, 15, 23, and 28) belonging to the group of cucumariosides I, has a main chain with terminal 3-O-methyl-xylose, sulfated glucose, quinovose and sulfated xylose and xylose as branching monosaccharide unit. Glycosides $11(\mathrm{~m} / z 702.2493$ $[\mathrm{M}-2 \mathrm{Na}]^{2-}$, calcd 702.2487), $15\left(\mathrm{~m} / \mathrm{z} 630.2098[\mathrm{M}-2 \mathrm{Na}]^{2-}\right.$, calcd 630.2093), $23(\mathrm{~m} / \mathrm{z} 693.2437$ $[\mathrm{M}-2 \mathrm{Na}]^{2-}$, calcd 693.2434), and $28\left(\mathrm{~m} / z\right.$ 694.2510 $[\mathrm{M}-2 \mathrm{Na}]^{2-}$, calcd 694.2512) were identified as cucumariosides $\mathrm{I}_{3}, \mathrm{I}_{4}, \mathrm{I}_{2}$, and $\mathrm{I}_{1}$, respectively, based on the comparison of their retention times, MS spectra and elemental compositions with those of standard compounds $[37,38]$.

Besides the described groups, two glycosides with trisaccharide chains were present in analyzed sample. In (-)MS/MS spectra of 33 (group X) (m/z 1029.4364 [M - Na] $]^{-}$, calcd 1029.4371) were detected fragment peaks at $m / z 519.1029\left[\mathrm{Glc}+\mathrm{Qui}^{+} \mathrm{XylSO}_{3}\right]^{-}, 867.3829\left[\mathrm{M}-\mathrm{Na}-\mathrm{Glc}^{-}\right.$, and 721.3245 [M - Na - Glc - Qui] $]^{-}$. In (-)MS/MS spectra of 35 (group XI) $\left(\mathrm{m} / z 999.4257[\mathrm{M}-\mathrm{Na}]^{-}\right.$, calcd 999.4265) were detected fragment peaks at $m / z 489.0899$ [Xyl + Qui $\left.+\mathrm{XylSO}_{3}\right]^{-}$and 867.3832 $[\mathrm{M}-\mathrm{Na}-\mathrm{Xyl}]^{-}$. Both glycosides probably have the same holostane type aglycone with $16 \beta-\mathrm{OAc}$ and two double bonds in side chains (probably 22E,24-diene).

Thus, all glycosides of E. fraudatrix can be divided into eleven groups in accordance with structures of oligosaccharide chains. Five types of oligosaccharide chains were not found in E. fraudatrix previously. According to literature data, the majority of triterpene glycosides of E. fraudatrix have 3-O-MeXyl as terminal monosaccharide unit. We revealed new glycosides with terminal 3-O-MeGlc residue $(22,27,34$, and 39); two of them (34, and 39) were isolated, and their tentative structures are further supported by 1D NMR (Figures S6-S8).

The fact that not all previously isolated glycosides have been found by LC-MS approach in this study of E. fraudatrix could be explained by the changes in the quantitative and qualitative composition of different components of the glycosidic fraction in the samples of one species collected in different places and seasons. A representative example of such changes has been reported for the components of the glycosidic fraction of Psolus fabricii, where two different glycosides were predominant or minor in the samples collected near Onekotan Island or Ushishir Islands (Kuril Islands) [41,42]. Another example is given by the glycosides of Massinium (=Neothynidium) magnum where the structures of glycosides 
from various places or various times of collection were strongly different [43]. In addition, some earlier isolated cucumariosides of A-group may be artifacts formed during the isolation process [24].

Obtained data allowed us to propose a biosynthetic pathway for oligosaccharide chains in E. fraudatrix (Figure 4), in agreement with the biosynthetic pathway of oligosaccharide chains proposed earlier [27]. The elongation of the oligosaccharide chain occurs by the addition of monosaccharide residues to various positions of the forming oligosaccharide chain. This leads to the formation of glycosides with different oligosaccharide chains. Sulfatation of triterpene glycosides may occur at different stages of the forming of carbohydrate chains resulting in the appearance of sulfated oligosaccharide moieties comprised from two to six sugar units. From this viewpoint, cucumarioside $B_{2}$ [27] having the same but non-sulfated carbohydrate chain as 35 represents a biosynthetic precursor of the new glycoside 35. Analogical relationships are observed in the series of isolated glycosides of E. fraudatrix: cucumariosides of C-group (I) $\rightarrow$ cucumariosides of H-group $(\mathrm{V}) \rightarrow$ cucumariosides of I-group (IX); cucumariosides of A-group (II) $\rightarrow$ cucumariosides of G-group (VI) $\rightarrow$ cucumariosides of F-group (VIII); and also in the groups III $\rightarrow$ VII detected by ESI MS.

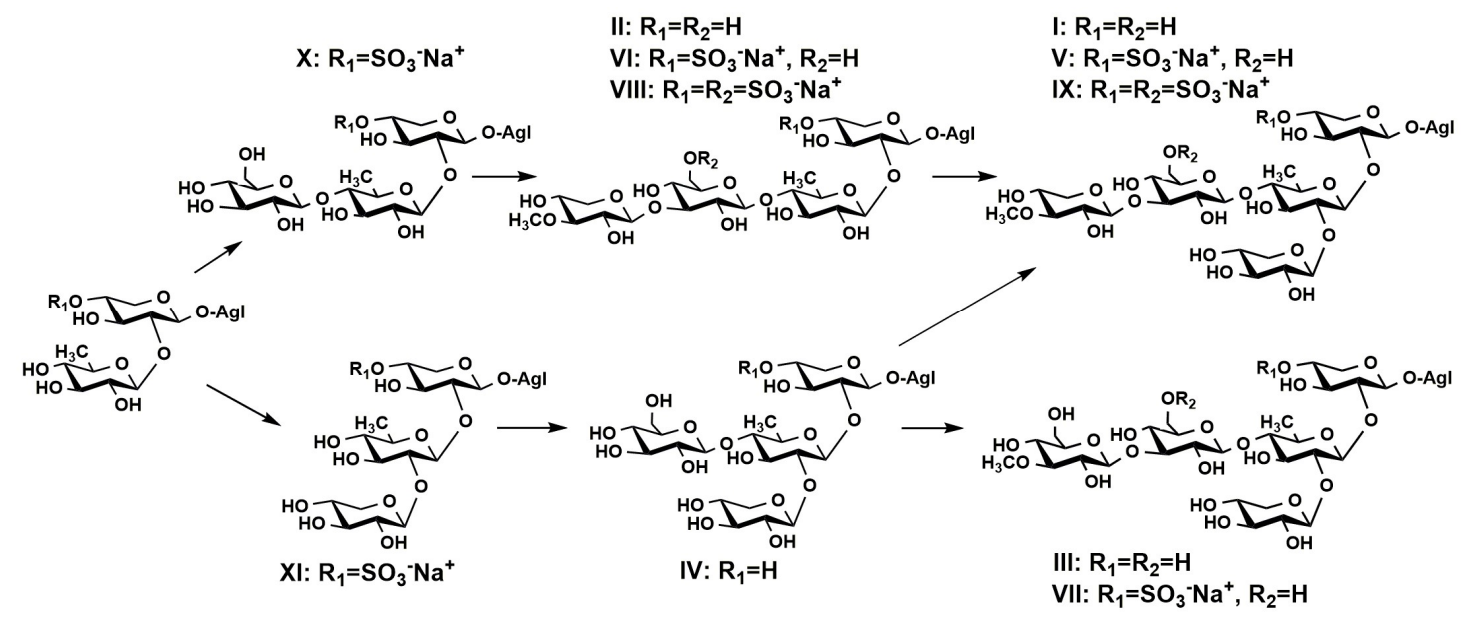

Figure 4. Hypothetic scheme of biosynthesis of oligosaccharide chains in E. fraudatrix.

\subsection{Distribution of Detected Glycosides in the Different Body Components}

Quantitative and qualitative analysis of detected triterpene glycosides in various body components of $E$. fraudatrix was also performed. We separately extracted triterpene glycoside mixtures from respiratory trees (RT), body walls (BW), gonad tubules (GN), guts $(\mathrm{G})$ and aquapharyngeal bulbs $(\mathrm{AB})$ and analyzed them by LC-ESI QTOF-MS. The profiling revealed that all the triterpene glycosides detected in the whole body extract were also present in all analyzed body parts.

The maximal content of overwhelming majority of the analyzed glycosides was observed in the body walls when compared with other body components of sea cucumber. This observation is a very good corroboration of a defensive role of triterpene glycosides. Since E. fraudatrix does not contain Cuvierian tubules, it accumulates the defensive molecules of triterpene glycosides in the body walls in order to indicate to predator its unpalatability. The main components of glycosidic fraction-cucumariosides $C_{1}$ (37) and $C_{2}(41)$, compounds 39 and 45 , as well as cucumariosides $F_{1}$ (38) and $G_{1}(32)$ - predominate in the body walls. These compounds contain pentasaccharide non-sulfated or tetrasaccharide mono- or disulfated carbohydrate chains making them highly hydrophilic substances and accelerating their diffusion to the surrounding water. Moreover, such compounds usually demonstrate significant membranolytic activities [1]. All these data also confirm the main external function of glycosides as chemical defense system.

The profiling of extracts from different body components revealed that relative amounts (normalized by sum and scaling) of most compounds were approximately the same (Figure 5; Figure S9). 
However, several minor compounds were more typical for certain body components. Relative amounts of compounds 12, 15, 17 and some others (Figure 5; Figures S9 and S10) are significantly higher in gonads than in body walls or other organs. The analysis of their structures revealed that compounds $\mathbf{1 5}$ and $\mathbf{1 7}$ have non-holostane aglycones with shortened side chains thus having structural similarity with steroidal hormones of vertebrates. It is known that sex hormones of vertebrates are biosynthesized from cholesterol via the cleavage of its side chain through the oxidation of C-20 and C-22 positions [44]. Actually, compound 12 contains a oxygen-bearing substituent in C-22 position as well as a oxidized C-20 position that makes it a putative biosynthetic precursor of the aglycones with shortened side chains such as $\mathbf{1 5}$ and 17. All these data are in good agreement with the earlier suggested internal biological function of the glycosides-the regulation of oocytes maturation in the sea cucumbers.

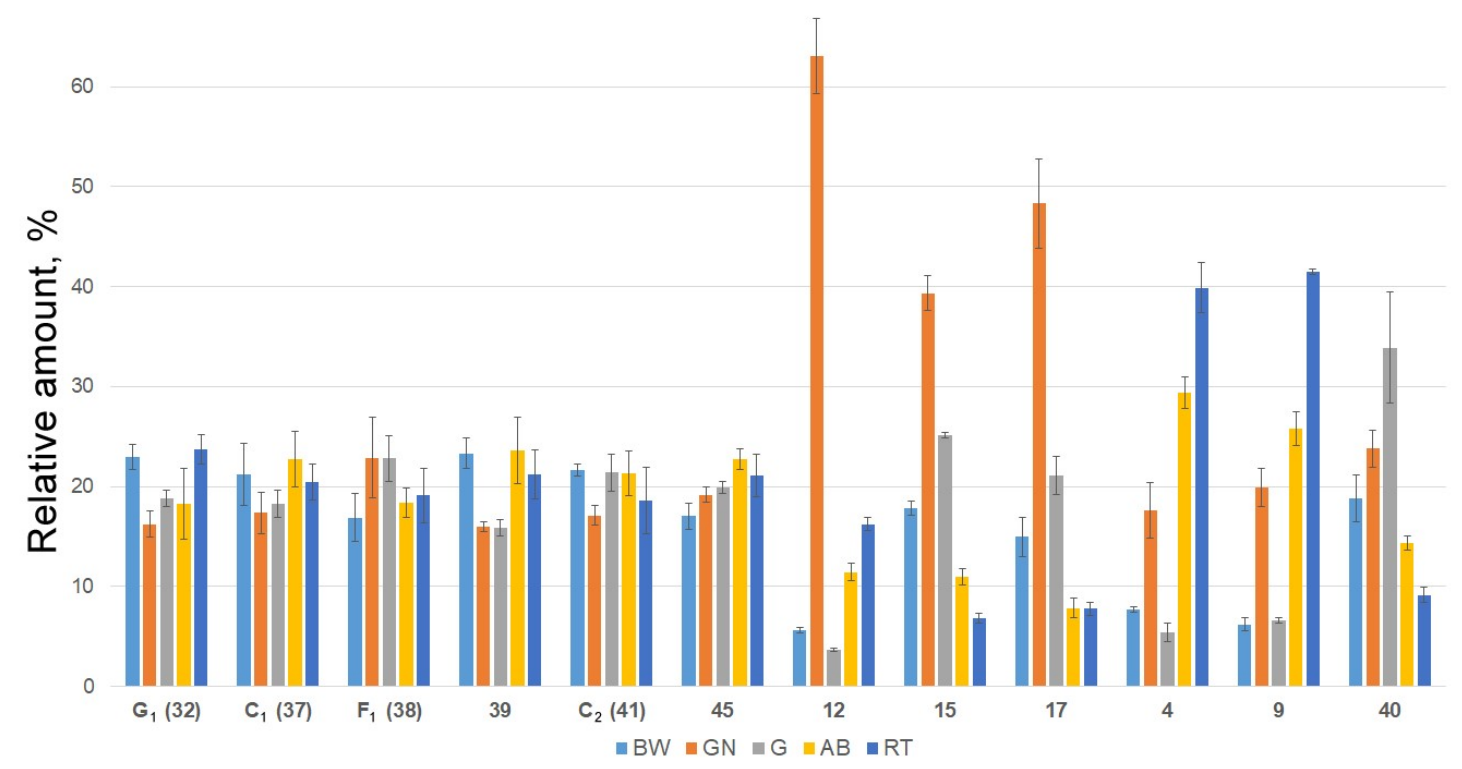

Figure 5. Relative quantities of triterpene glycosides cucumariosides $G_{1}(32), C_{1}(37), F_{1}(38)$ and $C_{2}(41)$, and compounds $39,45,12,15,17,4,9$, and 40 in respiratory trees (RT), gonads (GN), aquapharyngeal bulbs (AB), guts $(\mathrm{G})$ and body walls (BW) (bar plots represent the concentration in $\mu \mathrm{g} / \mathrm{g}$ animal material of metabolites (mean \pm SD) scaled by $100 \%$ ).

Interestingly, the glycosides of group IV (36 and 40) having peculiar "undeveloped" branched tetrasaccharide chains without methylated terminal sugar unit were characteristic for guts (Figure S11). There is a correlation between the contents of some glycosides in aquapharyngeal bulbs and respiratory trees (compounds 1, 2, 4, 5, 7, 8, and 9; Figure S9) that may indicate additional biological functions of triterpene glycosides in the organism-producer, which have to be investigated.

\section{Materials and Methods}

\subsection{Chemicals}

Methanol (quality HPLC gradient grade) and water (quality UV-HPLC grade) were obtained from Panreac (Barcelona, Spain). All other chemicals and reagents were of analytical grade or equivalent. Cucumariosides $\mathrm{A}_{1}-\mathrm{A}_{4}, \mathrm{~A}_{6}-\mathrm{A}_{15}$ [24,25], $\mathrm{H}, \mathrm{H}_{2}-\mathrm{H}_{8}$ [34,35,37], $\mathrm{F}_{1}-\mathrm{F}_{2}[36], \mathrm{I}_{1}-\mathrm{I}_{4}$ [37,38] isolated early from the E. fraudatrix and typicoside $\mathrm{A}_{2}$ isolated early from the sea cucumber Actinocucumis typica [45] were used as standards of triterpene glycosides. Structures of these compounds were established using different methods including high resolution NMR. 


\subsection{Animal Material}

Specimens of the sea cucumber Eupentacta fraudatrix (Djakonov et Baranova) (family Sclerodactylidae, order Dendrochirotida) were collected at Amursky Bay (Peter the Great Gulf, the Sea of Japan) in April 2017 at a depth of 1.0-1.5 m. Species identification was carried out by Dr. I.Yu. Dolmatov (A.V. Zhirmunsky Institute of Marine Biology, National Scientific Center of Marine Biology, Far Eastern Branch of Russian Academy of Sciences, Vladivostok, Russia). Voucher specimen No. PIBOC-2017-04-EF is preserved in the collection the G.B. Elyakov Pacific Institute of Bioorganic Chemistry.

\subsection{Sample Preparation and Solid-Phase Extraction (SPE)}

Seven fresh animals $(\mathrm{m}=3.9 \pm 1.3 \mathrm{~g})$ were chopped and extracted thrice with ethanol (totally $0.5 \mathrm{~L}$, for $10 \mathrm{~h}$ ). Other seven animals were dissected and separated into respiratory trees (RT, $\mathrm{m}=1.7 \mathrm{~g}$ ), body walls $(\mathrm{BW}, \mathrm{m}=10.2 \mathrm{~g})$, gonad tubules $(\mathrm{GN}, \mathrm{m}=3.9 \mathrm{~g})$, guts $(\mathrm{G}, \mathrm{m}=4.3 \mathrm{~g})$ and aquapharyngeal bulbs $(\mathrm{AB}, \mathrm{m}=3.9 \mathrm{~g})$. Metabolites from five different body components were extracted thrice with ethanol (totally $100 \mathrm{~mL}$, for $10 \mathrm{~h}$ ). Extracts were filtered, dried and reconstituted in $15 \mathrm{~mL}$ ethanol.

Two hundred microliters of the extract was centrifuged, and the supernatant was subjected solid-phase extraction (SPE). SPE cartridges (BondElut C18, $100 \mathrm{mg} / 1 \mathrm{~mL}$, Agilent Technologies, Santa Clara, CA, USA) were fitted into stopcocks and connected to a vacuum manifold. The sorbent was conditioned with $3 \mathrm{~mL}$ of ethanol followed by $3 \mathrm{~mL}$ water. Care was taken that the sorbent did not become dry during conditioning. With the stopcocks opened and the vacuum turned on, the samples were loaded onto the cartridge. The $100 \mu \mathrm{L}$ of extract were loaded into the SPE cartridge by drops. After sample addition, the SPE cartridge was washed with $1 \mathrm{~mL}$ of water. Glycosides were eluted with $1 \mathrm{~mL}$ of $100 \%$ ethanol. These extracts were dried and dissolved in $500 \mu \mathrm{L} 80 \% \mathrm{MeOH}$ in water $(v / v)$ and subjected to LC-MS analyses.

\subsection{LC-MS Analysis}

Analysis was performed using an Agilent 1200 series chromatograph (Agilent Technologies, Santa Clara, CA, USA) connected to a Bruker Impact II Q-TOF mass spectrometer (Bruker Daltonics, Bremen, Germany). Zorbax Eclipse XDB-C18 column $(1.0 \times 150 \mathrm{~mm}, 3.5 \mu \mathrm{m}$, Agilent Technologies, Santa Clara, CA, USA) with Zorbax SB-C8 guard-column $(2.1 \times 12.5 \mathrm{~mm}, 5 \mu \mathrm{m}$, Agilent Technologies, Santa Clara, CA, USA) were used for chromatographic separation. The mobile phases were $0.1 \%$ formic acid in $\mathrm{H}_{2} \mathrm{O}$ (eluent $\mathrm{A}$ ) and $0.1 \%$ formic acid in $\mathrm{MeOH}$ (eluent $\mathrm{B}$ ). The gradient program was as follows: isocratic at $60 \%$ of eluent $B$ from start to $3 \mathrm{~min}$, from $60 \%$ to $90 \%$ eluent B from 3 to $29 \mathrm{~min}$, from $90 \%$ to $100 \%$ eluent B from 29 to $30 \mathrm{~min}$, isocratic at $100 \%$ of eluent B to $35 \mathrm{~min}$, from $100 \%$ to $60 \%$ eluent B from 35 to $38 \mathrm{~min}$. After returning to the initial conditions, the equilibration was achieved after $15 \mathrm{~min}$. Chromatographic separation was performed at a $0.1 \mathrm{~mL} / \mathrm{min}$ flow rate at $40{ }^{\circ} \mathrm{C}$. Injection volume was $1 \mu \mathrm{L}$.

The mass spectrometry detection has been performed using ESI ionization source. Optimized ionization parameters for ESI were as follows: a capillary voltage of $\pm 4.0 \mathrm{kV}$, nebulization with nitrogen at 0.8 bar, dry gas flow of $7 \mathrm{~L} / \mathrm{min}$ at a temperature of $200{ }^{\circ} \mathrm{C}$. Metabolite profiles in positive ion mode were registered using post-column addition of $5 \times 10^{-4} \mathrm{M}$ sodium iodide at $60 \mu \mathrm{L} / \mathrm{h}$ flow rate for obtaining stabilized sodium adduct ions. Post-column infusion was performed with syringe pump via T-mixing tee. Based on the results of preliminary experiments, the mass spectra were recorded within $m / z$ mass range of 100-1500 and 70-1500 for MS/MS spectra (scan time $1 \mathrm{~s}$ ).

Collision induced dissociation (CID) product ion mass spectra were recorded in auto-MS/MS mode with a collision energy ranging from 75 to $125 \mathrm{eV}$ (an exact collision energy setting depended on the molecular masses of precursor ions). The precursor ions were isolated with an isolation width of $4 \mathrm{Th}$. 
The mass spectrometer was calibrated using the ESI-L Low Concentration Tuning Mix (Agilent Technologies, Santa Clara, CA, USA). Additionally a lock-mass calibration with hexakis $(1 \mathrm{H}, 1 \mathrm{H}, 3 \mathrm{H}$-tetrafluoropropoxy)phosphazine $(922.0098 \mathrm{~m} / \mathrm{z}$ in positive mode; $966.0007 \mathrm{~m} / \mathrm{z}$ in negative mode; Agilent Technologies, Santa Clara, CA, USA) was performed using Calibrant Reservoir Kit (Bruker Daltonics, Bremen, Germany). The instrument was operated using the otofControl (ver. 4.0, Bruker Daltonics, Bremen, Germany) and data were analyzed using the DataAnalysis Software (ver. 4.3, Bruker Daltonics, Bremen, Germany).

All tests were performed at least in triplicate. The results are expressed as the mean \pm standard deviation (SD).

\subsection{Quantitative Analysis of Detected Triterpene Glycosides in Various Body Component}

For quantitative analysis, we used cucumarioside $\mathrm{A}_{1}$ from E. fraudatrix [24] as a reference standard for non-sulfated glycosides $\left(\mathrm{R}_{2}=0.988\right)$, typicoside $\mathrm{A}_{2}$ from Actinocucumis typica [44] as a reference standard for monosulfated glycosides $\left(\mathrm{R}_{2}=0.999\right)$ and cucumarioside $\mathrm{I}_{2}$ from E. fraudatrix [37] as a reference standard for disulfated glycosides $\left(R_{2}=0.995\right)$. Standards at concentrations of 1.0, 2.5, 5.0, 10.0 and $50 \mu \mathrm{g} / \mathrm{mL}$ were used for building calibration curves (Figures S3-S5). All the experiments were carried out at least three times, LC-MS conditions are identical to those described above. As a result, the amounts of detected compounds were calculated through calibration curves. Results are shown in Table 1 as mean concentration in $\mu \mathrm{g} / \mathrm{g}$ animal organs.

For comparative analysis of the content of triterpene glycosides in different organs of E. fraudatrix data pretreatment was performed. With the aim to make feature compounds more comparable to each other, the datasets were adjusted using scaling by $100 \%$ (for $100 \%$-the total concentration of the compound in all organs). Results are shown in Figure 5 and Figures S9-S11 as the mean \pm standard deviation (SD).

\section{Conclusions}

Profiling of E. fraudatrix was performed by LC-ESI MS. Analysis of chromatographic behavior, MS and MS/MS data allowed the structural identification of the triterpene glycosides to be performed. Totally, 54 triterpene glycosides were found and structures of 44 constituents were proposed based on LC-ESI MS, chromatographic behavior and biogenetic hypotheses. In accordance with the structures of oligosaccharide chains, all analyzed glycosides of E. fraudatrix can be divided into eleven groups, and five of them were found in E. fraudatrix for the first time. A theoretical scheme of biogenesis of oligosaccharide chains in the studied species was given. The comparison of the qualitative and quantitative contents from the five different body components revealed that the profiles of some triterpene glycosides differed in the body walls and gonads indicating different external and internal biological functions of these compounds. The predominance of the main highly hydrophilic and membranolytic glycosides of E. fraudatrix in the body walls confirms their defensive role. The presence of glycosides in all body components of E. fraudatrix indicates their multifunctionality.

Supplementary Materials: The following are available online at www.mdpi.com/1660-3397/15/10/302/s1, Table S1: Fragmentation of the different types of oligosaccharide chains determined in triterpene glycosides from the ethanol extract of the sea cucumber E. fraudatrix, Figure S1: LC-ESI MS base-peak chromatogram (a) and total compounds chromatogram (b) of ethanol extract of sea cucumber Eupentacta fraudatrix in negative ion mode, Figure S2: Fragment of ESI MS/MS spectrum of $[\mathrm{M}+\mathrm{Na}]^{+}$precursor ion at $m / z 1121$ of cucumarioside $\mathrm{A}_{1}$, Figure S3: Calibration curve for cucumarioside $\mathrm{A}_{1}$ (ion $[\mathrm{M}-\mathrm{H}]^{-}$at $m / z$ 1097), Figure S4: Calibration curve for typicoside $\mathrm{A}_{2}$ (ion $[\mathrm{M}-\mathrm{Na}]^{-}$at $m / z$ 1177), Figure S5: Calibration curve for cucumarioside $\mathrm{I}_{2}$ (ion $[\mathrm{M}-2 \mathrm{Na}]^{2-}$ at $m / z$ 693), Figure S6: ${ }^{13} \mathrm{C}$ NMR spectrum of glycoside 39, Figure S7: ${ }^{1} \mathrm{H}$ NMR spectrum of glycoside 39, Figure S8: ${ }^{1} \mathrm{H}$ NMR spectrum of glycoside 34, Figure S9; Relative quantities of triterpene glycosides detected in E. fraudatrix in body walls $(\mathrm{BW})$, gonads (GN), guts $(\mathrm{G})$, aquapharyngeal bulbs $(\mathrm{AB})$, and respiratory trees (RT) (bar plots represent the concentration in $\mu \mathrm{g} / \mathrm{g}$ animal material of metabolites (mean $\pm \mathrm{SD}$ ) scaled by $100 \%$ ), Figure S10: Relative quantities of triterpene glycosides grouped by aglycone structures detected in $E$. fraudatrix in respiratory trees $(\mathrm{RT})$, gonads $(\mathrm{GN})$, aquapharyngeal bulbs $(\mathrm{AB})$, guts $(\mathrm{G})$ and body walls $(\mathrm{BW})$ (bar plots represent the concentration in $\mu \mathrm{g} / \mathrm{g}$ animal material of metabolites (mean $\pm \mathrm{SD}$ ) scaled by $100 \%$ ), Figure S11: Relative quantities 
of triterpene glycosides grouped by sugar moiety structures detected in E. fraudatrix in respiratory trees (RT), gonads (GN), aquapharyngeal bulbs (AB), guts $(\mathrm{G})$ and body walls (BW) (bar plots represent the concentration in $\mu \mathrm{g} / \mathrm{g}$ animal material of metabolites (mean $\pm \mathrm{SD}$ ) scaled by $100 \%$ ).

Acknowledgments: The study was supported by Grant No. 16-13-10185 from the RSF (Russian Science Foundation).

Author Contributions: Roman S. Popov and Natalia V. Ivanchina conceived and designed the project, performed experiments, analyzed the data and wrote the manuscript; Alexandra S. Silchenko, Sergey A. Avilov and Vladimir I. Kalinin isolated standard compounds, discussed results and wrote the manuscript; Igor Yu. Dolmatov performed preparation of animal material; and Valentin A. Stonik and Pavel S. Dmitrenok supervised research and discussed results.

Conflicts of Interest: The authors declare no conflict of interest.

\section{References}

1. Kalinin, V.I.; Aminin, D.L.; Avilov, S.A.; Silchenko, A.S.; Stonik, V.A. Triterpene glycosides from sea cucumbers (Holothurioidea, Echinodermata), biological activities and functions. In Studies in Natural Product Chemistry (Bioactive Natural Products); Atta-ur-Rahman, Ed.; Elsevier Science Publisher: Amsterdam, The Netherlands, 2008; Volume 35, pp. 135-196.

2. Careaga, V.P.; Maier, M.S. Cytotoxic triterpene glycosides from sea cucumbers. In Handbook of Anticancer Drugs from Marine Origin; Kim, S.-K., Ed.; Springer International Publishing: Cham, Switzerland, 2015; pp. 515-528.

3. Chludil, H.D.; Murray, A.P.; Seldes, A.M.; Maier, M.S. Biologically active triterpene glycosides from sea cucumbers (Holothuroidea, Echinodermata). In Studies in Natural Products Chemistry; Atta-ur-Rahman, Ed.; Elsevier Science Publisher: Amsterdam, The Netherlands, 2003; Volume 28, pp. 587-615.

4. Kim, S.K.; Himaya, S.W.A. Triterpene glycosides from sea cucumbers and their biological activities. Adv. Food Nutr. Res. 2012, 63, 297-319.

5. Maier, M.S.; Roccatagliata, A.J.; Kuriss, A.; Chludil, H.; Seldes, A.M.; Pujol, C.A.; Damonte, E.B. Two new cytotoxic and virucidal trisulfated triterpene glycosides from the antarctic sea cucumber Staurocucumis liouvillei. J. Nat. Prod. 2001, 64, 732-736. [CrossRef] [PubMed]

6. Aminin, D.L.; Menchinskaya, E.S.; Pisliagin, E.A.; Silchenko, A.S.; Avilov, S.A.; Kalinin, V.I. Anticancer activity of sea cucumber triterpene glycosides. Mar. Drugs 2015, 13, 1202-1223. [CrossRef] [PubMed]

7. Aminin, D.L.; Pislyagin, E.A.; Menchinskaya, E.S.; Silchenko, A.S.; Avilov, S.A.; Kalinin, V.I. Immunomodulatory and anticancer activity of sea cucumber triterpene glycosides. In Studies in Natural Products Chemistry (Bioactive Natural Products); Atta-ur-Rahman, Ed.; Elsevier Science Publisher: Amsterdam, The Netherlands, 2014; Volume 41, pp. 75-94.

8. Bordbar, S.; Anwar, F.; Saari, N. High-value components and bioactives from sea cucumbers for functional foods-A review. Mar. Drugs 2011, 9, 1761-1805. [CrossRef] [PubMed]

9. Van Dyck, S.; Flammang, P.; Meriaux, C.; Bonnel, D.; Salzet, M.; Fournier, I.; Wisztorski, M. Localization of secondary metabolites in marine invertebrates: Contribution of MALDI MSI for the study of saponins in Cuvierian tubules of H. forskali. PLoS ONE 2010, 5, e13923. [CrossRef] [PubMed]

10. Van Dyck, S.; Caulier, G.; Todesco, M.; Gerbaux, P.; Fournier, I.; Wisztorski, M.; Flammang, P. The triterpene glycosides of Holothuria forskali: Usefulness and efficiency as a chemical defense mechanism against predatory fish. J. Exp. Biol. 2011, 214, 1347-1356. [CrossRef] [PubMed]

11. Aminin, D.L.; Anisimov, M.M. The influence of holotoxin $\mathrm{A}_{1}$ to the $\mathrm{Ca}^{2+}$-transport and meiotic maturation of oocytes from the sea cucumber Stichopus japonicus. J. Evol. Biochem. Physiol. 1990, 26, 9-13.

12. Kalinin, V.I.; Avilov, S.A.; Silchenko, A.S.; Stonik, V.A. Triterpene glycosides of sea cucumbers (Holothuroidea, Echinodermata) as taxonomic markers. Nat. Prod. Commun. 2015, 10, 21-26. [PubMed]

13. Van Dyck, S.; Gerbaux, P.; Flammang, P. Qualitative and quantitative saponin contents in five sea cucumbers from the Indian Ocean. Mar. Drugs 2010, 8, 173-189. [CrossRef] [PubMed]

14. Bondoc, K.G.V.; Lee, H.; Cruz, L.J.; Lebrilla, C.B.; Juinio-Mecez, M.A. Chemical fingerprinting and phylogenetic mapping of saponin congeners from three tropical holothurian sea cucumbers. Comp. Biochem. Physiol. B 2013, 166, 182-193. [CrossRef] [PubMed]

15. Van Dyck, S.; Gerbaux, P.; Flammang, P. Elucidation of molecular diversity and body distribution of saponins in the sea cucumber Holothuria forskali (Echinodermata) by mass spectrometry. Comp. Biochem. Physiol. B 2009, 152, 124-134. [CrossRef] [PubMed] 
16. Dolmatov, I.Y.; Ivantey, V.A. Histogenesis of longitudinal muscle bands in holothurians. Russ. J. Dev. Biol. 1993, 24, 67-72.

17. Dolmatov, I.Y.; Yushin, V.V. Larval development of Eupentacta fraudatrix (Holothuroidea, Dendrochirota). Asian Mar. Biol. 1993, 10, 123-132.

18. Dolmatov, I.Y. Regeneration of the aquapharyngeal complex in the holothurian Eupentacta fraudatrix (Holothuroidea, Dendrochirota). In Monographs in Developmental Biology; Taban, C.H., Boilly, B., Eds.; Karger: Basel, Switzerland, 1992; Volume 23, pp. 40-50.

19. Mashanov, V.S.; Dolmatov, I.Y.; Heinzeller, T. Transdifferentiation in holothurian gut regeneration. Biol. Bull. 2005, 209, 184-193. [CrossRef] [PubMed]

20. Lamash, N.E.; Dolmatov, I.Y. Proteases from the regenerating gut of the holothurian Eupentacta fraudatrix. PLoS ONE 2013, 8, e58433. [CrossRef] [PubMed]

21. Zaika, O.A.; Dolmatova, L.S. Cooperative apoptosis of coelomocytes of the holothurian Eupentacta fraudatrix and its modulation by dexamethasone. Adv. Biosci. Biotechnol. 2013, 4, 908-917. [CrossRef]

22. Dolmatova, L.S.; Ulanova, O.A.; Dolmatov, I.Y. Comparative study of the effect of dexamethasone and new holothurians' extract on the level of the cytokine similar substances in certain immune cells types in the holothurian Eupentacta fraudatrix. Pac. Med. J. 2014, 34-38.

23. Dolmatova, L.S.; Ulanova, O.A. Dexamethasone treatment in vitro resulted in different responses of two fractions of phagocytes of the holothurian Eupentacta fraudatrix. Russ. J. Mar. Biol. 2015, 41, 503-506. [CrossRef]

24. Silchenko, A.S.; Kalinovsky, A.I.; Avilov, S.A.; Andryjaschenko, P.V.; Dmitrenok, P.S.; Martyyas, E.A.; Kalinin, V.I. Triterpene glycosides from the sea cucumber Eupentacta fraudatrix. Structure and biological action of cucumariosides $\mathrm{A}_{1}, \mathrm{~A}_{3}, \mathrm{~A}_{4}, \mathrm{~A}_{5}, \mathrm{~A}_{6}, \mathrm{~A}_{12}$ and $\mathrm{A}_{15}$, seven new minor non-sulfated tetraosides and unprecedented 25-keto, 27-norholostane aglycone. Nat. Prod. Commun. 2012, 7, 517-525. [PubMed]

25. Silchenko, A.S.; Kalinovsky, A.I.; Avilov, S.A.; Andryjaschenko, P.V.; Dmitrenok, P.S.; Martyyas, E.A.; Kalinin, V.I. Triterpene glycosides from the sea cucumber Eupentacta fraudatrix. Structure and cytotoxic action of cucumariosides $\mathrm{A}_{2}, \mathrm{~A}_{7}, \mathrm{~A}_{9}, \mathrm{~A}_{10}, \mathrm{~A}_{11}, \mathrm{~A}_{13}$ and $\mathrm{A}_{14}$, seven new minor non-sulfated tetraosides and an aglycone with an uncommon 18-hydroxy group. Nat. Prod. Commun. 2012, 7, 845-852. [PubMed]

26. Silchenko, A.S.; Kalinovsky, A.I.; Avilov, S.A.; Andryjashenko, P.V.; Dmitrenok, P.S.; Kalinin, V.I.; Stonik, V.A. $3 \beta$-O-Glycosylated $16 \beta$-acetoxy-9 $\beta$-H-lanosta-7,24-diene-3 $\beta, 18,20 \beta$-triol, an intermediate metabolite from the sea cucumber Eupentacta fraudatrix and its biosynthetic significance. Biochem. Syst. Ecol. 2012, 44, 53-60. [CrossRef]

27. Silchenko, A.S.; Kalinovsky, A.I.; Avilov, S.A.; Andryjaschenko, P.V.; Dmitrenok, P.S.; Martyyas, E.A.; Kalinin, V.I. Triterpene glycosides from the sea cucumber Eupentacta fraudatrix. Structure and biological activity of cucumariosides $B_{1}$ and $B_{2}$, two new minor non-sulfated unprecedented triosides. Nat. Prod. Commun. 2012, 7, 1157-1162. [PubMed]

28. Afiyatullov, S.S.; Kalinovskii, A.I.; Stonik, V.A. Structure of cucumariosides $C_{1}$ and $C_{2}-2$ New triterpene glycosides from the Eupentacta fraudatrix holothurian. Khim. Prir. Soedin. 1987, 6, 831-837. [CrossRef]

29. Afiyatullov, S.S.; Tishchenko, L.Ya.; Stonik, V.A.; Kalinovskii, A.I.; Elyakov, G.B. The structure of cucumarioside $\mathrm{G}_{1}-\mathrm{A}$ new triterpene glycoside from the sea cucumber Cucumaria fraudatrix. Khim. Prir. Soedin. 1985, 2, 244-248.

30. Kalinin, V.I.; Avilov, S.A.; Kalinovskii, A.I.; Stonik, V.A.; Milgrom, Yu.M.; Rashkes, Ya.V. Cucumarioside G ${ }_{4}-A$ new triterpene glycoside from the holothurian Eupentacta fraudatrix. Khim. Prir. Soedin. 1992, 6, 600-603.

31. Kalinin, V.I.; Avilov, S.A.; Kalinovskii, A.I.; Stonik, V.A. Cucumarioside $\mathrm{G}_{3}-$ A minor triterpene glycoside from the holothurian Eupentacta fraudatrix. Khim. Prir. Soedin. 1992, 6, 635-636. [CrossRef]

32. Avilov, S.A.; Kalinin, V.I.; Makarieva, T.N.; Stonik, V.A.; Kalinovsky, A.I. Structure of cucumarioside $\mathrm{G}_{2}$, a novel nonholostane glycoside from the sea cucumber Eupentacta fraudatrix. J. Nat. Prod. 1994, 57, 1166-1171. [CrossRef] [PubMed]

33. Kalinin, V.I.; Kalinovskii, A.I.; Afiyatullov, S.S. Triterpene glycosides of the holothurin Eupentacta pseudoquinquisemita. Khim. Prir. Soedin. 1988, 2, 221-225.

34. Silchenko, A.S.; Kalinovsky, A.I.; Avilov, S.A.; Andryjaschenko, P.V.; Dmitrenok, P.S.; Yurchenko, E.A.; Kalinin, V.I. Structure of cucumariosides $\mathrm{H}_{5}, \mathrm{H}_{6}, \mathrm{H}_{7}$ and $\mathrm{H}_{8}$, triterpene glycosides from the sea cucumber Eupentacta fraudatrix and unprecedented aglycone with 16,22-epoxy-group. Nat. Prod. Commun. 2011, 6, 1075-1082. [PubMed] 
35. Silchenko, A.S.; Kalinovsky, A.I.; Avilov, S.A.; Andryjaschenko, P.V.; Dmitrenok, P.S.; Yurchenko, E.A.; Kalinin, V.I. Structures and cytotoxic properties of cucumariosides $\mathrm{H}_{2}, \mathrm{H}_{3}$ and $\mathrm{H}_{4}$ from the sea cucumber Eupentacta fraudatrix. Nat. Prod. Res. 2012, 26, 1765-1774. [CrossRef] [PubMed]

36. Popov, R.S.; Avilov, S.A.; Silchenko, A.S.; Kalinovsky, A.I.; Dmitrenok, P.S.; Grebnev, B.B.; Ivanchina, N.V.; Kalinin, V.I. Cucumariosides $F_{1}$ and $F_{2}$, two new triterpene glycosides from the sea cucumber Eupentacta fraudatrix and their LC-ESI MS/MS identification in the starfish Patiria pectinifera, a predator of the sea cucumber. Biochem. Syst. Ecol. 2014, 57, 191-197. [CrossRef]

37. Silchenko, A.S.; Kalinovsky, A.I.; Avilov, S.A.; Andryjaschenko, P.V.; Dmitrenok, P.S.; Menchinskaya, E.S.; Aminin, D.L.; Kalinin, V.I. Structure of cucumarioside $\mathrm{I}_{2}$ from the sea cucumber Eupentacta fraudatrix (Djakonov et Baranova) and cytotoxic and immunostimulatory activities of this saponin and relative compounds. Nat. Prod. Res. 2013, 27, 1776-1783. [CrossRef] [PubMed]

38. Silchenko, A.S.; Kalinovsky, A.I.; Avilov, S.A.; Andryjaschenko, P.V.; Dmitrenok, P.S.; Martyyas, E.A.; Kalinin, V.I. Triterpene glycosides from the sea cucumber Eupentacta fraudatrix. Structure and biological action of cucumariosides $\mathrm{I}_{1}, \mathrm{I}_{3}, \mathrm{I}_{4}$, three new minor disulfated pentaosides. Nat. Prod. Commun. 2013, 8, 1053-1058. [PubMed]

39. Domon, B.; Costello, C.E. A systematic nomenclature for carbohydrate fragmentations in FAB-MS/MS spectra of glycoconjugates. Glycoconj. J. 1988, 5, 397-409. [CrossRef]

40. Antonov, A.S.; Kalinovsky, A.I.; Afiyatullov, S.S.; Leshchenko, E.V.; Dmitrenok, P.S.; Yurchenko, E.A.; Kalinin, V.I.; Stonik, V.A. Erylosides $\mathrm{F}_{8}, \mathrm{~V}_{1}-\mathrm{V}_{3}$, and $\mathrm{W}-\mathrm{W}_{2}-\mathrm{New}$ triterpene oligoglycosides from the Carribean sponge Erylus goffrilleri. Carbohydr. Res. 2017, 449, 153-159. [CrossRef] [PubMed]

41. Kalinin, V.I.; Kalinovskii, A.I.; Stonik, V.A. The structure of psolusoside A-The major triterpene glycoside of the sea cucumber Psolus fabricii. Khim. Prir. Soedin. 1985, 2, 212-217.

42. Kalinin, V.I.; Kalinovskii, A.I.; Stonik, V.A.; Dmitrenok, P.S.; Elkin, Y.N. Structure of psolusoside B-A nonholostane triterpene glycoside of the holothurian genus Psolus. Khim. Prir. Soedin. 1989, 3, 361-368. [CrossRef]

43. Silchenko, A.S.; Kalinovsky, A.I.; Avilov, S.A.; Kalinin, V.I.; Andrijaschenko, P.V.; Dmitrenok, P.S.; Chingizova, E.A.; Ermakova, S.P.; Malyarenko, O.S.; Dautova, T.N. Nine new triterpene glycosides, magnumosides $\mathrm{A}_{1}-\mathrm{A}_{4}, \mathrm{~B}_{1}, \mathrm{~B}_{2}, \mathrm{C}_{1}, \mathrm{C}_{2}$ and $\mathrm{C}_{4}$, from the Vietnamese sea cucumber Neothyonidium (=Massinium) magnum: Structures and activities against tumor cells independently and in synergy with radioactive irradiation. Mar. Drugs 2017, 15, 256. [CrossRef] [PubMed]

44. Heftman, E.; Mosettig, E. Biochemistry of Steroids; Reinhold Publishing Corporation: New York, NY, USA, $1960 ;$ p. 231.

45. Silchenko, A.S.; Kalinovsky, A.I.; Avilov, S.A.; Andryjaschenko, P.V.; Dmitrenok, P.S.; Martyyas, E.A.; Kalinin, V.I.; Jayasandhya, P.; Rajan, G.C.; Padmakumar, K.P. Structures and biological activities of typicosides $\mathrm{A}_{1}, \mathrm{~A}_{2}, \mathrm{~B}_{1}, \mathrm{C}_{1}$ and $\mathrm{C}_{2}$, triterpene glycosides from the sea cucumbers Actinocucumis typica. Nat. Prod. Commun. 2013, 8, 301-310. [PubMed]

(C) 2017 by the authors. Licensee MDPI, Basel, Switzerland. This article is an open access article distributed under the terms and conditions of the Creative Commons Attribution (CC BY) license (http:// creativecommons.org/licenses/by/4.0/). 